\title{
Vertebrate evolution on the Indian raft - Biogeographic conundrums
}

\author{
${ }^{1}$ Department of Geology, University of Jammu, Jammu - 180006, India; E-mail: varunparmarvp@gmail.com \\ ${ }^{2}$ Department of Geology, Centre for Advanced Studies, University of Delhi, Delhi - 110007, India; \\ *Corresponding author, E-mail: guntupalli.vrprasad@gmail.com
}

(Received : 9/09/2019; Revised accepted : 28/10/2019)

https://doi.org/10.18814/epiiugs/2020/020029

The Indian plate has a long history of rifting, drifting and collision. It travelled for about $9000 \mathrm{~km}$ from its position within Gondwana to reach its present position within Asia. During its northward journey, the Indian landmass remained physically isolated for about $35 \mathrm{Ma}$ from all other landmasses after its final break-up from Madagascar. A critical examination of the vertebrate fossil record of the Indian plate for the period of early and late drift phases offers very limited information for the early drift phase, but reveals a complex biogeographic history for the late drift phase. The fauna of late drift phase is represented by taxa of both Gondwanan and Laurasian affinities and some endemic forms that originated in the Indian subcontinent and later dispersed out of it. The close relationship between different Late Cretaceous vertebrate clades of the Indian subcontinent and Madagascar is explained through dispersal over a terrestrial route consisting Seychelles, Amirante Ridge, Providence Bank, and some microcontinental fragments. On the other hand, the presence of Laurasian taxa in the Late Cretaceous of the India is accounted by the island arcs and oceanic islands that existed to the north of Greater India in the Late Cretaceous. In other words, the Indian plate served as a 'stepping stone' between Madagascar and Laurasia.

\section{Introduction}

The modern day fauna of the Indian subcontinent is a mixture of ancestral Gondwanan clades, Laurasian immigrants, and endemic radiations resulting from its past journey from a southern high latitude position to its present position north of the equator. But how, when and what fauna migrated into or out of the Indian plate is not exactly known and hence it remains an active field of research. According to the palaeogeographic reconstructions, the supercontinent Pangea remained intact until the Late Jurassic, whereafter it started to break apart into the northern landmass of Laurasia and the southern landmass of Gondwana. This separation was slow, such that only a narrow seaway opened up between Laurasia and Gondwana. Towards the end of the Jurassic ( 167 Ma) fragmentation of Gondwana into East and West Gondwana occurred (Lawver et al., 1991). East Gondwana comprised landmasses such as India, Madagascar, Antarctica, and Australia whereas West Gondwana consisted of Africa and South America (Lawver et al., 1991). Later in the Early Cretaceous ( 130 $\mathrm{Ma}$ ), the Indo-Madagascar-Seychelles block was separated from the Antarctica-Australia block. This was followed by split between Indiathe Seychelles from Madagascar in the Late Cretaceous ( 90 Ma) (Storey et al., 1995), whereafter India drifted in isolation for about next $35 \mathrm{Ma}$ at a rapid rate of about $15-20 \mathrm{~cm}$ /year. During this rapid drift phase, the Indian landmass passed over the Réunion hotspot in the latest Cretaceous-earliest Palaeocene as manifested by the Deccan volcanic eruptions of western and central India which led to the separation of the Seychelles from India by the Early Palaeocene ( $\sim 64$ Ma). Finally, the Indian plate collided with Asia between 55 and 50 Ma (Chatterjee et al., 2013, 2017 and references therein). In slight variation to this sequence of tectonic events, Chatterjee et al. (2013, 2017) opined that after breaking from Madagascar, the Indian subcontinent established links with Africa, Arabia and Europe by way of Oman-Kohistan-Ladakh Arcs at about $80 \mathrm{Ma}$, i.e., before the Deccan volcanic eruption and remained in isolation between 67 to 55 Ma (Fig. 1).

The Indian landmass, thus located in the Southern Hemisphere contiguous to South America, Africa, Madagascar, Australia, and Antarctica at the beginning of break-up of Pangaea, made the longest journey of all the continents after its separation from Gondwana to reach Asia covering almost $9000 \mathrm{~km}$ in about 160 million years (Chatterjee et al., 2013). During this arduous voyage, the changing position of the Indian plate aided by eustatic sea level and climate changes and volcanic activity influenced the origin, evolution, radiation, and extinction of its life forms. What happens when a landmass travels such a long distance and remains physically isolated for a major part of its journey? Did endemic fauna and flora evolve on the Indian plate during its isolation phase as was the case with Australia, Madagascar or South America? Were there any faunal exchanges between India and other landmasses during its physical 


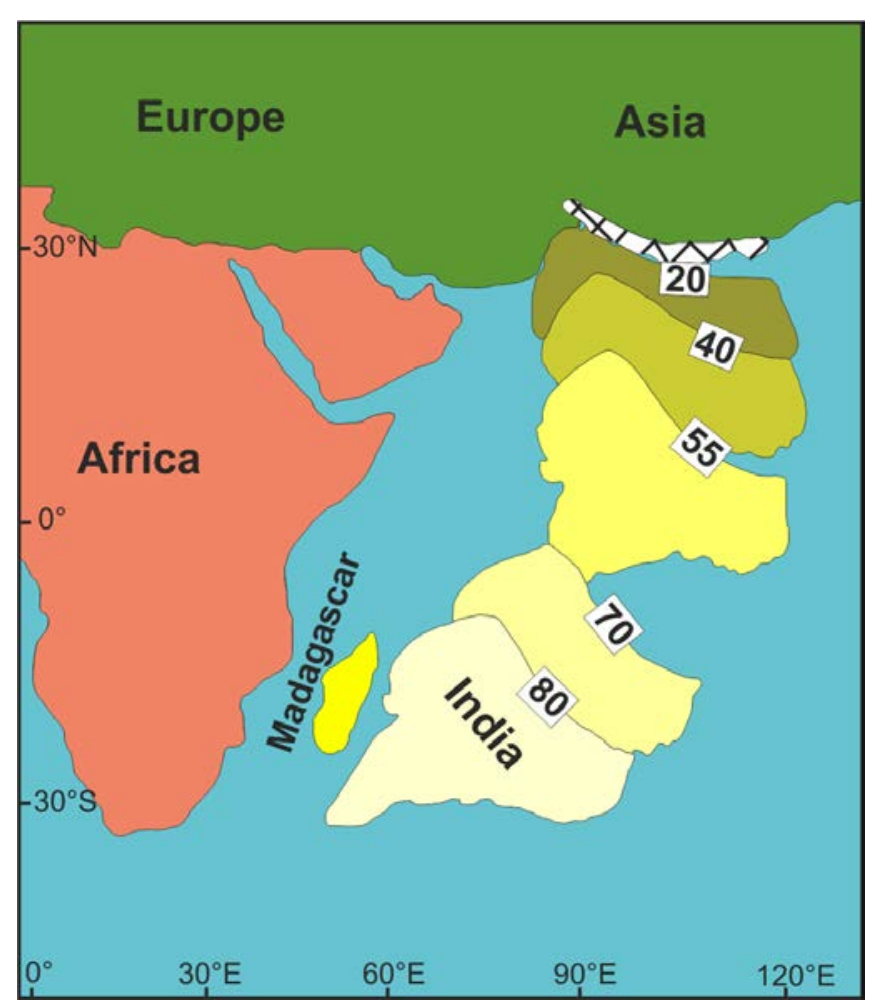

Figure 1. Depicts the northward journey of India following the separation of India from Madagascar in the Late Cretaceous (modified after Powell, 1979).

isolation? If there were biotic dispersals between India and Gondwana or Laurasia, what was the mode of dispersal? To address these questions, the fossil record representing different phases (pre-drift, syn-drift, pre-collision) of India's northward journey needs to be closely examined.

The vertebrate fauna of the pre-drift phase of the Indian plate comes from the Late Permian to Jurassic Gondwana sedimentary basins located in south and central India. A detailed account of the pre-drift phase vertebrate fauna of the Upper Gondwana formations is presented by Bandyopadhyay and Ray (this volume). The Rajmahal Trap marks the end of the Gondwana amalgamation and therefore, the sediments deposited during this time interval represent the early drift-phase rocks such as the vertebrate fauna yielding Early Cretaceous Gangapur Formation and Rajmahal intertrappean beds of the Gondwana basins, and the Raghavapuram Mudstone and the Karai Formation occurring outside the Gondwana basins. As the drifting continued, sediments deposited during the Late Cretaceous preserved the remains of vertebrates that lived during the late drift phase of India, such as the Bagh Group, the Kallamedu Formation, the Lameta Formation, and the Deccan intertrappean beds. The Palaeocene strata of late drift phase, such as the Palana, Fatehgarh, Akli, and Vagadkhol formations have yielded very few vertebrate fossils and offer very limited information on the Palaeocene palaeobiogeographic history of India. However, the Lower Eocene vertebrate rich Cambay Shale Formation throws light on the pre-collision phase vertebrate fauna of India. Bajpai and Kapur (this volume) deliberate on the diversity and evolution of pre-collision Early Eocene fauna. In the following sections, we present the vertebrate palaeobiogeographic history of the Indian plate during the syn-drift phase.

\section{Vertebrate faunal record of the syn-drift phase of India and biogeographic affinities}

\section{Early drift phase}

The drift phase of the Indian plate is marked by its break-up from Gondwanan continents followed by Rajmahal volcanism in eastern India, a long interval of geographic isolation, and the eruption of Deccan Traps. During the early drift phase, as the Indian plate moved over the Kerguelen hot plume, the Indo-Madagascar block got separated from Australia-Antarctica block at about 120-130 Ma concomitant with Rajmahal volcanic eruption. This led to the development of a large sedimentary basin along its eastern coast (Veevers et al., 1991), represented today by the Cauvery Basin located in the southern Indian state of Tamil Nadu. The Cauvery Basin, due to several transgressive-regressive events, hosts marine, coastal, and fluvio-deltaic sediments of Early Cretaceous-Miocene age (Sundaram et al., 2001). Covering an area of about $25,000 \mathrm{~km}^{2}$, the Cetaceous sedimentary succession of the Cauvery basin is divisible into three groups, Uttatur, Trichinopoly and Ariyalur in this order of ascendance (Sundaram et al., 2001). The sequence is best exposed in the Ariyalur sub-basin. Though vertebrate fossils have been first reported from here in the $19^{\text {th }}$ century (Egerton, 1845; Blanford, 1862; Lydekker 1879), only recently a better picture of vertebrate diversity has emerged with new discoveries from the shallow marine Karai Formation (Underwood et al., 2011; Verma et al., 2012) and the continental Kallamedu Formation (Gaffney et al., 2001; Prasad et al., 2013; Goswami et al.,2013; Halliday et al., 2016).

The vertebrate fauna of the Cauvery basin largely comes either from the early drift phase Lower Albian to Middle Turonian Karai Formation of the Uttatur Group (Blanford, 1862; Stoliczka, 1873; Lydekker, 1879; Gowda, 1967; Paul, 1973; Ayyasami and Das, 1990; Underwood et al., 2011; Verma et al., 2012), or from the late drift phase Upper Cretaceous (Maastrichtian) Kallamedu Formation of the Ariyalur Group (Lydekker, 1879; Yadagiri and Ayyasami, 1989; Gaffney et al., 2001; Prasad et al., 2013; Goswami et al., 2012, 2013; Halliday et al., 2016). In recent years, attempts have been made to ascertain the biotic affinities of the vertebrate taxa recovered from this basin (Underwood et al., 2011; Verma et al., 2012; Prasad et al., 2013; Goswami et al., 2013; Verma, 2015; Halliday et al., 2016, 2017).

The Karai Formation (Fig. 2) yielded a reasonably diverse pelagic or benthopelagic chondrichthyan fauna comprising Protosqualus sp., Gladioserratus magnus, ?Notidanodon sp., Cretalamna appendiculata, Dwardius sudindicus, ?Eostriatolamia sp., Squalicorax aff. baharijensis, Cretodus longiplicatus (Underwood et al., 2011), and Ptychodus decurrens (Verma et al., 2012). Among these, Protosqualus sp., Gladioserratus magnus, ?Notidanodon sp., Dwardius sudindicus are known from high latitude, cold water environments of northern Europe and Australia, whereas, Cretalamna appendiculata is a cosmopolitan species, and Cretodus longiplicatus was reported from both equatorial and mid-southern latitudes. The fossil reports by Egerton (1845), Stoliczka (1873), Gowda (1967) and Paul (1973) need to be re-examined before commenting on their intercontinental affinities. As per our current understanding, the chondrichthyan fauna of the Karai Formation consists largely of high latitude cool water forms restricted to northern Europe, North America and Australia with an antitropical distribution (Underwood et al., 


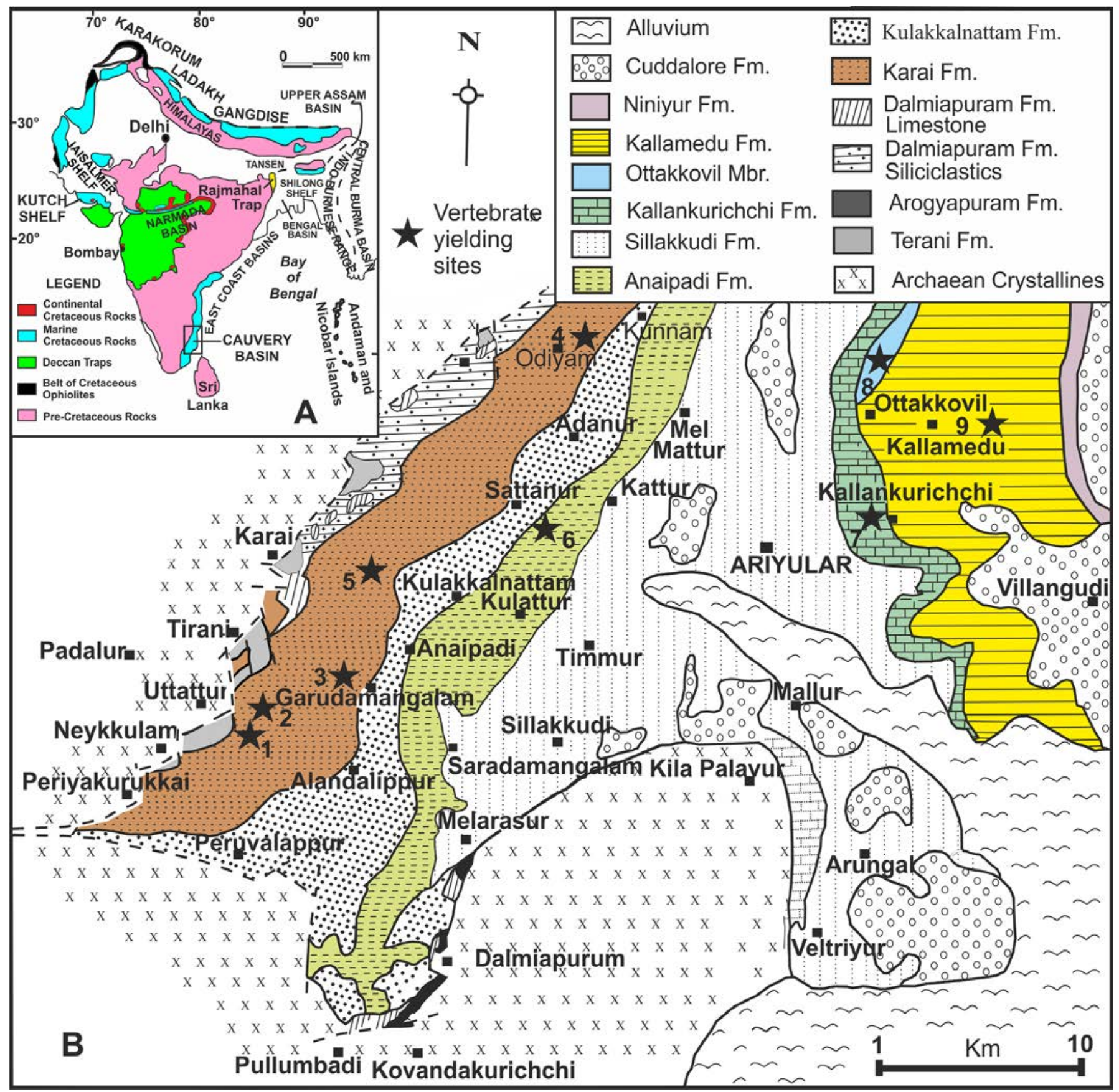

Figure 2.A. Map of India showing the distribution of Cretaceous rocks in India including the location of Rajmahal Traps (Rajmahal Hills) and Cauvery Basin. B. Geological map of the Ariyalur sub-basin (Cauvery Basin) showing various Cretaceous formations and important vertebrate fossil sites (map adapted from Sundaram et al., 2001); 1-5. Vertebrate-bearing sites within the Early Albian-Middle Turonian Karai Formation, 6. Dinosaur yielding site in the Coniacian Anaipadi Formation, 7. Megaloolithus cylindricus (sauropod dinosaur egg) bearing Lower Maastrichtian Kallankuruchchi Formation, 8. Fusioolithus baghensis (sauropod eggshell fragments) yielding marine lower part of the Upper Maastrichtian Kallamedu Formation, 9. Vertebrate fossil site in the upper continental part of the Upper Maastrichtian Kallamedu Formation.

2011). This is consistent with the high latitude position of India during this time.

Although a fossil egg of a supposed chelonian was reported from the Uttatur Group, its taxonomic affinities are yet to be ascertained (Sahni, 1957). An inner mold of an indeterminate carapace and plastron of a bothremydid turtle was reported from the Karai Formation from a site near Kunnam village (Fig. 2B) (Muzzy, 1956 in Ayyasami and Das, 1990), but whereabouts of these specimens is unknown. Ichthyosaur vertebrae of the Karai Formation assigned to Ichthyosaurus indicus (Lydekker, 1888) and teeth referred to Platypterygius indicus (Underwood et al., 2011) have recently been placed in Ichthyosauria indet. and Platypterygiinae indet., respectively (Prasad et al., 2017a). An isolated vertebra collected from the Odiyam Member of the Karai Formation was assigned to Platypterygius sp. indet. by Ayyasami et al. (2016). Platypterygiinae had a cosmopolitan distribution, with known occurrences from North America and Europe 
(England, France, Russia, and Germany) in Laurasia and Argentina, Australia and Colombia in Gondwana.

The three other sedimentary units of the early drift phase are the Lower Cretaceous Gangapur Formation of Pranhita-Godavari valley, the Lower Cretaceous Raghavapuram Mudstone of the southeast coast of India and the Lower Cretaceous Rajmahal intertrappean beds. The Kerguelen plume eruption at $118 \mathrm{Ma}$ was responsible for the formation of Rajmahal Traps of eastern India and break-up of the Indian landmass from Antarctica -Australia (Kent et al., 2002). The sedimentary layers (intertrappean) intercalated with the Rajmahal Traps (Fig. 2A) and deposited during the dormant stages of volcanism have yielded a prolific Ptilophyllum flora and only a single clupeiform fish Jhingrania roonwali (Mishra and Saxena, 1964). From the Gangapur Formation, only few actinopterygian fish teeth (Gyrolepis and Caturus-like teeth) are known (Prasad et al., 2004), whereas from the marine Raghavapuram Mudstone (Fig.3), impressions of fish scales, spines and fragmentary skeletons of Clupeiformes have been reported (Baksi, 1972). These finds, however, do not offer much on the palaeobiogeographic relationships of the Indian subcontinent during its early drift phase.

\section{Late drift phase}

During the late drift phase, dismemberment of Madagascar from the Indo-Seychelles block took place around $\sim 88-90$ Ma as a consequence of Marion hot plume activity. Subsequent to this, the Indian plate passed over the Réunion hotspot resulting in the eruption of Deccan Traps at the Cretaceous/Palaeogene boundary (66 Ma) and separation of the Indian landmass from the Seychelles. The fossil record of this phase comes mainly from the Bagh Group of Narmada valley, the Upper Cretaceous Lameta Formation and the intertrappean sedimentary beds of the Deccan Volcanic Province (DVP), and the Upper Cretaceous Anaipadi, Kallankuruchchi and Kallamedu formations of the Cauvery Basin.

\section{Narmada Valley}

The Bagh Group of the lower Narmada valley in central India represents a sequence formed due to a marine incursion from the western margin of India in the Late Cretaceous. The Bagh Group is divided into the Nimar Sandstone, the Nodular Limestone and the Coralline or Bryozoan Limestone in this order of superposition (Jaitly and Ajane, 2013). The sequence begins with the freshwater lower part of the Nimar Sandstone which changes to marine in the upper part yielding oyster shells and shark teeth. The overlying Nodular Limestone and the Coralline Limestone are purely marine in nature and the entire sequence ranges from Cenomanian to Coniacian in age (Jaitly and Ajane, 2013). Although some shark taxa were documented from the Nimar Sandstone by Verma (1965) and Das Sarma and Sinha (1966), morphological details were not given and the illustrations were very poor. Khosla et al. (2003) documented fragmentary limb bones of a sauropod dinosaur from the red clays of the basal part of the Nimar Sandstone. Morphological features indicate close affinities to Saltasaurus, a titanosaur from the Late Cretaceous of Argentina

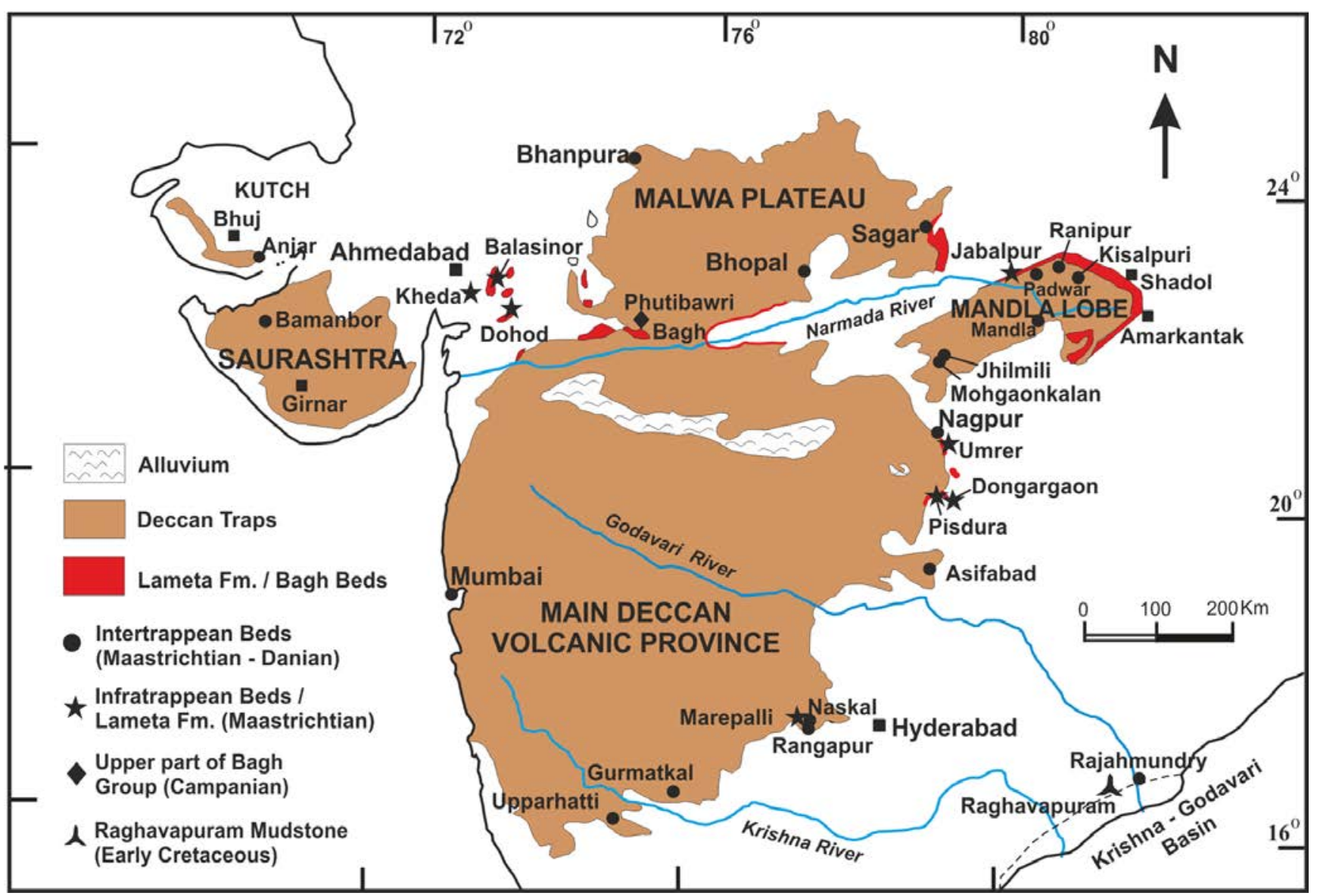

Figure 3. Shows the distribution of Deccan Traps in peninsular India and various fossiliferous Deccan infratrappean (Lameta Formation) and intertrappean sites, the Bagh Group of sediments, and location of the Raghavapuram Mudstone. 
(Khosla et al., 2003). Recent field prospecting in the Cretaceous sequences of the lower Narmada valley has led to the discovery of isolated archosaur teeth from an oyster-bearing green sandstone bed occurring at the top of the Coralline Limestone (Coniacian) from a site near Phutibawri village, Dhar District, Madhya Pradesh (Fig. 3). Of the three teeth recovered from this horizon, two are identified with abelisaurid dinosaurs and the third one with an indeterminate crocodile (Prasad et al., 2016). These fossils, conforming to the premaxillary and maxillary tooth morphology of Majungasaurus and Indosuchus, pre-date the earlier abelisaurid dinosaur reports from the Upper Cretaceous (Maastrichtian) Lameta Formation of Jabalpur, Pisdura (Central India) and Balasinor (Western India) and the Upper Cretaceous (Maastrichtian) Kallamedu Formation (South India). The same green sandstone bed at the top of the youngest geological unit (the Coralline Limestone) of the Bagh Group also yielded an elasmobranch fauna comprising Ptychodus sp., Scapanorhynchus sp. aff. S. raphiodon Agassiz, 1844, Cretodus sp. aff. C. crassidens (Dixon, 1850), Cretalamna sp., Squalicorax sp. aff. S. falcatus Agassiz, 1843, and Elasmobranchii indet. (Prasad et al., 2017b). This assemblage, previously widely documented from the Cretaceous deposits of North America, western Europe, North and West Africa, Far East and Near East from the Tethys belt, demonstrates that there was a clear change in elasmobranch faunal composition of India from cool temperate water forms in the early Late Cretaceous to essentially subtropical to tropical forms tracking the changing position of India during its northward drift.

\section{Cauvery Basin}

As the northward drift of India continued, sediments of the Trichinopoly and Ariyalur groups were deposited in the Ariyalur subbasin of the Cauvery basin. Yadagiri and Ayyasami (1979) reported a partial skull and postcranial skeleton, attributed to a stegosaur Dravidosaurus blanfordi, from the Coniacian Anaipadi Formation of the Trichinopoly Group from a site near Siranattam village (Fig. 2). Latter examination of these bones led others to doubt its identification (Chatterjee and Rudra, 1996; Wilson et al., 2011), or regard it as nomen dubium (Maidment et al., 2008) or ?Stegosauria indet. (Pereda-Suberbiola et al., 2015).

Vertebrate fossils have been recovered at three levels within the Maastrichtian interval. A sauropod dinosaur egg belonging to Megaloolithus cylindricus (Ariyalur Group), originally known from the Upper Cretaceous Lameta Formation of Cental India, was described from the shallow marine Upper Cretaceous (Lower Maastrichtian) Kallankuruchchi Formation (Fig. 2) (Kohring et al., 1996). More recently, Dhiman et al. (2017) reported sauropod dinosaur eggshell fragments representing Fusioolithus baghensis (Fernández and Khosla, 2015) from the shallow marine lower part of the Upper Cretaceous (Upper Maastrichtian) Kallamedu Formation (= Ottakovil Formation of Sastry et al., 1977) (Fig. 2). Eggshells with microstructure similar to that of M. cylindricus have been described from the Upper Cretaceous rocks of France and Upper Cretaceous Allen Formation of Argentina (Fernández and Khosla, 2015). Megaloolithus pseudomammilare from the Upper Maastrichtian deposits of Aix-en-Provence, France and Tremp Basin, Spain and Patagoolithus salitralensis from the Upper Cretaceous of Salitral Moreno, Argentina were also considered as junior synonyms of $F$. baghensis (Fernández and Khosla, 2015). Hence this sauropod oospecies demonstrate close palaeobiogeographic links with both
Southern Hemisphere continents and southern Europe.

The upper continental part of the Kallamedu Formation (Fig. 2) is long known for its fragmentary dinosaur bones (Blanford, 1862; Matley, 1929). Large limb and girdle bones comparable to those of titanosaurid sauropods of the Lameta Formation of Central India were identified in the fossil bones from the Kallamedu Formation (Matley, 1929). Yadagiri and Ayyasami (1979) reported bones of theropod, sauropod, and stegosaur dinosaurs from the Kallamedu Formation and described some of them as representing a new theropod dinosaur Bruhathkayosaurus matleyi. According to Galton and Ayyasami (2017), the bones of B. matleyi do not exist any more as they disintegrated in the plaster jackets before reaching Geological Survey of India headquaters and B. matleyi is now regarded either as nomen dubium or Sauropoda indet. (Upchurch et al., 2004; Krause et al., 2006; Hone et al., 2016). Following a detailed study of supposed ornithischian dinosaur bone identified as a stegosaur dermal plate from the Upper Cretaceous Kallamedu Formation (Anonymous, 1978), Galton and Ayyasami (2017) concluded that this bone probably belongs to a sauropod. The Kallamedu Formation yielded remains of fishes: Lepisosteidae indet., Egertonia sp. (Prasad et al., 2013; Halliday et al., 2016); amphibian: Anura indet. (Prasad et al., 2013); turtle: Kurmademys kallamedensis (Gaffney et al., 2001); crocodiles: cf. Simosuchus sp., Crocodylia indet. (Prasad et al., 2013); dinosaurs: Abelisauridae indet. (Prasad et al., 2013), Troodontidae indet. (Goswami et al., 2013); and mammals: Sudamericidae indet. (Goswami et al., 2012). An isolated theropod tooth described from the Kallamedu site as Megalosaurus sp. by Lydekker (1879) may actually belong to the abelisaurid dinosaurs.

The Kallamedu fauna thus has clades that have pan-Gondwanan affinities (gondwanatherian mammals and abelisaurid dinosaurs) (Goswami et al., 2012; Prasad et al., 2013) or Madagascan affinities (Egertonia sp., Kurmademys, simosuchid crocodyliform) (Gaffney et al., 2001; Prasad et al., 2013; Halliday et al., 2016) on one hand and a clade of Laurasian affinity such as troodontid theropod dinosaur (Goswami, et al., 2013) on the other hand. Halliday et al. (2017) comparing fauna of all the Late Cretaceous localities of India and Madagascar demonstrated that the faunal composition of the Kallamedu Formation is distinct fromthat of the Deccan infra- and intertrappean beds, rather it shows greater faunal similarity with the Upper Cretaceous Maevarano Formation of Madagascar, despite the fact that the two landmasses were separated several million years ago.

\section{Deccan Volcanic Province}

During the late drift phase, the Indian plate passed over the Réunion hot plume which resulted in the eruption of Deccan flood basalts and splitting of the Seychelles from the Indian landmass. The Deccan Traps extruded in three major pulses interspersed with quiescent periods of considerable time; 1 ) phase I ( 6\% volume) occurred close to the base of C30n at ca. 67.4 Ma within the Maastrichtian, 2 ) phase II ( $~ 80 \%$ volume) erupted within C29r close to the Cretaceous-Palaeogene transition over a short period of time ranging from thousands to tens of thousands of years, 3) phase III ( 14\% volume) eruption took place at or near the base of C29n within the early Danian (Chenet et al., 2007, 2008, 2009; Jay and Widdowson, 2008; Jay et al., 2009; Schoene et al., 2015). Currently, the Deccan basalts occur in four major geographical provinces of peninsular India, viz., Main Deccan Volcanic Province, Mandla Lobe, Saurashtra, and 
Malwa Plateau (Fig. 3). The Upper Cretaceous Lameta Formation (underlying the oldest basalt flow) and the sedimentary beds occurring intercalated with the Deccan lava flows (= intertrappean beds) have been an important source of vertebrate fossils representing the late drift phase of India. These Maastrichtian strata associated with the Deccan volcanic province (DVP) are the most intensively sampled Cretaceous rocks in India. A diversified vertebrate assemblage comprising all major groups of vertebrates except birds have been reported from the infra- and intertrappean beds (refer to Prasad, 2012 for the faunal list). This fauna consists of mixed Gondwanan and Laurasian clades.

\section{Taxa of Gondwanan affinity}

The Gondwanan clades are represented by amphibians: Indobatrachus pusillus (Myobatrachidae), Leptodactylidae indet., Hemisotidae indet., Hylidae indet., Ranoidea indet.; snakes: Indophis sahnii (Nigerophiidae), Madtsoia pisdurensis, Sanajeh indicus (Madtsoiidae), Coniophis sp. (Aniliidae), turtles: Carteremys leithii, 'Carteremys' pisdurensis, Podocnemididae indet., Sankuchemys sethnai, Bothremydidae indet., Taphrosphy ssp.; dinosaurs: Jainosaurus septentrionalis, Isisaurus colberti, ?Hypselosaurus sp., Titanosauriformes indet. (sauropods), Indosuchus raptorius, Indosaurus matleyi, Rajasaurus narmadensis, Lametasaurus indicus, Laevisuchus indicus, Rahiolisaurus gujaratensis (abelisaurid theropods); mammals: Bharattherium bonapartei (Sudamericidae), Avashishta bacharamensis (see Prasad, 2012 for references). The myobatrachid (Indobatrachus), leptodactylid, ranoid and hylid amphibians are known from South America and Africa and are thus considered Gondwanan clades (Prasad and Rage, 1995, 2004). Prasad and de Lapparent de Broin (2002) had shown that isolated crocodilian teeth from the Deccan intertrappean beds appear to be morphologically similar to those of ziphodont crocodiles such as Hamadasuchus from the Early Cretaceous of Africa, and/or to Mahajangasuchus from the Late Cretaceous of Madagascar. The snake remains from the Deccan volcanic province assigned to nigerophiid Indophis sahnii and madtsoiids Sanajeh indicus and Madtsoia pisdurensis, and Madtsoiidae indet. (Rage and Prasad, 1992; Rage et al., 2004; Wilson et al., 2010; Mohabey et al., 2011) are Gondwanan snakes with known fossil records from the Cretaceous of South America, Madagascar and Africa. The Indian abelisaurid dinosaurs (such as Indosuchus, Laevisuchus, Lametasaurus, Rajasaurus, Rahiolisaurus) show phylogenetic affinities with Late Cretaceous Majungasaurus and Carnotaurus of Madagascar and South America, respectively (Wilson et al., 2003; Novas et al., 2010), whereas, the Indian dinosaur ootaxa show close resemblance to forms known from France, Spain, Africa and Argentina (Fernández and Khosla, 2015; Dhiman et al., 2018). In a review of parataxonomy of Late Cretaceous sauropod egg species of India and Argentina, Fernández and Khosla (2015) observed that five oospecies, viz., Megaloolithus jabalpurensis, M. cylindricus, $M$. megadermus, Fusioolithus baghensis, and F. berthei, are common to India, Argentina, Africa and southern Europe. According to them, a close phylogenetic relationship exists between the oospecies of India and southern Europe, and between Patagonia (Argentina), India and Africa. Gondwanatherian (Sudamericidae) mammals were first documented from the Campanian of South America and were considered endemic to this continent. Later, they were documented from the Maastrichtian of India and Madagascar and the Eocene of Antarctica (Scillato-Yané and Pascual, 1984; Bonaparte, 1986; Krause et al., 1997) which implies that they had pan-Gondwanan distribution. Doubtful sudamericid mammals are also known from the Upper Cretaceous rocks of Tanzania (Krause et al., 2003). The haramiyidan mammals, though considered a Laurasian group since its oldest reports are known from the Late Triassic to Middle Jurassic of Europe and North America, have also been documented from the Late Jurassic of Tanzania and Early Cretaceous of Morocco and thus considered as relict forms of a formerly widely distributed group (Sigogneau-Russell, 1991; Heinrich, 1999; Hahn and Hahn, 2003).

\section{Taxa of Laurasian affinity}

The Laurasian clades include anurans: Pelobatidae indet., Costata incertae sedis, Gobiatinae indet.; lizards: Anguidae gen. et sp. indet., dinosaurs: Troodontidae indet., and mammals: Kharmerungulatum vanvaleni. The pelobatid, Gobiatinae and Costata frogs and Anguidae lizards had Laurasian origin and did not arrive in Gondwanan continents prior to early Palaeogene except India where they occur in the Upper Cretaceous intertrappean beds (Prasad and Rage, 1991, 1995, 2004; Rage et al., in press). Kharmerungulatum is morphologically similar to archaic ungulates Protungulatum and Baioconodon of North America (Prasad et al., 2007b). As a diverse assemblage of zhelestid mammals, possibly representing the ancestral stock for archaic ungulates of North America, has been documented from 85 Ma old rocks of West Asia (Archibald, 1996), Kharmerungulatum was interpreted as an immigrant from Laurasia. The troodontid theropod dinosaur reported from the Kallamedu Formation is the only report of this essentially Laurasian group from the Gondwana.

\section{Indian subcontinent as a centre of origin/ out-of-India dispersals}

It is assumed that following the split from Madagascar, the Indian plate served as a 'biotic ferry' carrying the Gondwanan lineages in isolation and offloaded the constituent biota on coming into contact with the Asian mainland. This was designated as "out-of-India" dispersal hypothesis (Krause and Maas, 1990; Bossuyt and Milinkovitch, 2001). Bossuyt and Milinkovitch's (2001) hypothesis was based on molecular phylogeny of modern ranid frogs and over the years, it received further support from similar studies, such as that of cichlid and aplocheiloid fishes, ratite and passerine birds, caecilian amphibians, acrodont lizards, and Crypteroniaceae and Melastomataceae plants (Macey et al., 2000; Bossuyt and Milinkovitch, 2001; Cooper et al., 2001; Gower et al., 2002; Conti et al., 2002; Sparks, 2004; Bossuyt et al., 2006). Likewise, floral remains recorded from the DVP such as Poaceae, and nonmarine diatoms (Ambwani et al., 2003; Prasad et al., 2005, 2011) have also lent support to out-of-India dispersal hypothesis.

Evidence for biotic endemicity on the Indian plate, which remained physically isolated from other landmasses for about $35 \mathrm{Ma}$ has been garnered from both living and fossil taxa. Molecular phylogeny of the extant frog Nasikabatrachus sahyadrensis (Nasikabatrachidae) from the Western Ghats has revealed Jurassic ancestry for this anuran family and since then it remained endemic to India (Biju and Bossuyt, 2003). Likewise, the caecilian amphibian family Chikilidae from northeast India diverged from the African family Herpelidae about $140 \pm 20$ m.y. ago and remained endemic to 
this part of India (Kamei et al., 2012). Recent detailed study of turtle remains (mainly postcranial bones) from the intertrappean beds of Upparhatti, southwestern part of DVP revealed that the Indian Late Cretaceous turtles appear to be endemic at the generic level when precisely identified (de Lapparent de Broin and Prasad, in press) and share only plesiomorphic or homoplastic characters with Late Cretaceous bothremydid turtles of Gondwana. In fact, a high diversity of endemic species has been recorded among the ostracods. More than 100 species of ostracods have been reported so far from the Deccan intertrappean beds, of which $98 \%$ species were regarded as endemic to India (Whatley and Bajpai, 2006). In view of their oldest occurrences and high diversity in the Late Cretaceous of India, Whatley (2012) favoured Indian origin and out-of-India dispersal for Gomphocythere, Cypridopsis and Eucypris.

In addition to these, adapisoriculid mammals documented from the Upper Cretaceous Deccan intertrappean beds (currently represented by Deccanolestes hislopi, D. robustus, D. narmadensis and Sahnitherium rangapurensis (Prasad and Sahni, 1988; Prasad et al., 1994, 2010; Rana and Wilson, 2003; Goswami et al., 2011)) are the only confirmed eutherian mammals known from the Cretaceous of Gondwana. The Indian adapisoriculid mammals are the most primitive with relatively high diversity. Derived forms appear in younger horizons (Palaeocene- Eocene) of NW Africa (Afrodon) and Europe (Afrodon, Bustylus). It is thus inferred that India was the centre of origin for adapisoriculid mammals in the Late Cretaceous and their dispersal to Africa and Europe took place close to the CretaceousPalaeogene (K/Pg) boundary (Prasad et al., 2010; Smith et al., 2010; Goswami et al., 2011). Additionally, the discovery of oldest fossil fruits of the vine family Vitaceae (Indovitis chitaleyae Manchester et al., 2013) in the Deccan intertrappean beds of Central India support an Indian origin for this group and out-of-India dispersal to Laurasia in the Palaeocene-Eocene times. Recently, Baas et al. (2017) reported oldest remains of eudicot plant wood belonging to the family Connaraceae (Connaroxylon dimorphum) from the Deccan intertrappean beds and inferred an Indian origin and out-of-India dispersal for this family.

The out-of-India dispersal hypothesis implies that only one way dispersal from India to Asia was possible following the collision between these two landmasses. However, Yuan et al. (2018) have shown that Natatanuran frogs with African origins had dispersed to Asia between 75.6 and 72.8 Ma using a terrestrial route (India as a 'stepping stone'). In the reverse direction, the mantellid frogs of Asian ancestry had possibly dispersed to Madagascar close to K/Pg boundary possibly using the same land connection (Van der Meijden et al., 2007; Kurabayashi et al., 2008).

\section{India-Madagascar biogeographic link}

Considering the more recent ( $\sim 88 \mathrm{Ma}$ ) separation of Madagascar from India with respect to other Gondwanan landmasses, Late Cretaceous terrestrial vertebrates of India and Madagascar are expected to be closely related to each other than to any other landmass. Indeed, Late Cretaceous vertebrate faunas of India and Madagascar confirm this. The presence of closely related taxa may be attributed to former wide spread distribution of the ancestral stocks in the Gondwana before its break-up and the Late Cretaceous similarities are the result of retention of primitive morphological traits in the descendants (Ali and Krause, 2011) or alternatively they reflect the more recent biogeographic connections between these landmasses.
Close phylogenetic relationships have been established between nigerophiid snake Indophis fanambinana (Pritchard et al., 2014), madtsoiid snake Madtsoia madagascarensis, bothremyid turtle Kinkonychelys hechti (Gaffney et al., 2009), and gondwanatherian mammal Lavanify miolaka (Krause et al., 1997) of Madagascar and Indophis sahnii (Rage and Prasad, 1992), Madtsoia pisdurensis (Mohabey et al., 2011), Kurmademys kallamedensis (Gaffney et al., 2001), and Bharattherium bonapartei (Prasad et al., 2007a) of India, respectively. Similarly, the phyllolepid fish Egertonia and Simosuchuslike crocodyliform reported from the Kallamedu Formation, India are the only known reports of these taxa outside Madagascar (Prasad et al., 2013; Halliday et al., 2016). Based on these faunal similarities, we subscribe to the view that faunal dispersal routes existed in the Late Cretaceous between India, Madagascar, Africa and Europe. This view receives further support from the recent phylogenetic study of Arcovenator, an abelisaurid dinosaur from the Late Cretaceous of France. Tortosa et al. (2014), while discussing the phylogenetic relationships of this large-bodied Late Campanian abelisaurid, posited that a close phylogenetic relationship exists between Arcovenator and Maastrichtian abelisaurids from India (Rajasaurus, Indosaurus, Rahiolisaurus) and Madagascar (Majungasaurus) rather than with small-bodied European abelisaurids, and nested them within the subfamily Majungasaurinae. This implies that these taxa had a geographically closer common ancestor than other Gondwanan abelisaurids such as brachyrostrans of South America. According to Tortosa et al. (2014), dispersal of Majungasaurinae abelisaurids between the Indian subcontinent, Madagascar and Europe via Africa was possible through some terrestrial links. A similar dispersal route has been favoured for Sabalites dindoriensis, a coryphoid palm of Laurasian origin, present in the Upper Cretaceous intertrappean beds of Central India (Srivastava et al., 2014).

\section{Potential modes of faunal exchanges}

One of the greatest biogeographic conundrums of India's drift history is its biological connectivity with adjacent continents. Palaeogeographic maps depict the Indian plate as an island fully isolated from other landmasses following its separation from Madagascar around $88 \mathrm{Ma}$ until its collision with the Asian mainland at about $55 \mathrm{Ma}$. This implies that India was a 'Noah's Ark'or a 'Biotic Ferry’ during its Late Cretaceous drift without any physical connection with other landmasses and may have developed endemic biota which later dispersed into Asia following its collision with the latter. Contrary to the long held view that faunal interchanges could take place between these land masses only after collision between India and Asia, Sahni (1984) suggested that the Late Cretaceous biota of the Deccan volcanic province is cosmopolitan in nature with close affinities to Gondwanan and Laurasian faunas. He speculated on the presence of possible filter corridors between Africa and India through the Mascarene Plateau and Chagos-Laccadive Ridge that facilitated biotic dispersals during the Late Cretaceous. In view of the biotic similarities between South America, India and Madagascar, and India and Laurasia, it was debated whether there were any northern or southern land bridges/landspans or stepping-stones, such as island-arcs, oceanic islands or microcontinents that facilitated faunal and floral dispersals into and out of India during its rapid drifting phase (Briggs, 1989, 2003; Krause et al., 1997; Rage, 1996, 2003; Prasad and Sahni, 1999, 2009; Ali and Aitchison, 2009; Prasad et al., 2010; Chatterjee et al., 2013, 2017). 
In order to explain similar faunas in India, Madagascar, and South America, Krause et al. (1997) envisaged a terrestrial connection between South America and India-Madagascar via Antarctica and Kerguelen Plateau (Krause et al., 1997; Hay et al., 1999) in the Late Cretaceous, whereas Case (2002) argued that Antarctica and Madagascar were linked by the Gunnerus Ridge during the mid-Late Cretaceous rather than through Kerguelen Plateau (Fig. 4). Ali and Aitchison (2009) have shown that these southern land bridges were submerged by the end of Early Cretaceous ( $115 \mathrm{Ma}$ ) and deep water gaps developed between northward moving Indo-Madagascar block and Antarctica inhibiting any faunal interchanges. Ali and Krause (2011), while rejecting the southern connection between South America and Indo-Madagascar-Seychelles block around 88 million years ago through Kerguelen Plateau or Gunnerus Ridge, suggested that many Late Cretaceous taxa of South America, India and Madagascar may represent relictual lineages that evolved vicariantly from their ancestral stocks somewhere in Gondwana during the Early and "middle" Cretaceous time.

To explain the presence of faunas with Laurasian affinities within the intertrappean beds an early India/Asia collision at the $\mathrm{K} / \mathrm{Pg}$ boundary was proposed by Jaeger et al. (1989) (Fig. 5A). However, geophysical data and sedimentary record at the northern margin of India do not support this hypothesis (Prasad and Sahni, 1999). Prasad and Sahni (1999, 2009), on the other hand, postulated that the faunal exchange between India and Asia prior to their collision occurred through sweepstakes dispersals across the Tethys Sea (Fig. 5D, Fig. 6). According to them, the Trans Himalayan Arc, Kohistan and Dras island arcs and oceanic islands that were consumed at the subduction zone may have served as 'stepping stones' for faunal dispersals. To strengthen their argument they pointed out that the faunal elements involved in such an exchange were small-sized tetrapods such as pelobatid, Gobiatidae, and Costata anurans, Anguidae lizards, and charophytes. However, the report of a troodontid dinosaur, an essentially Laurasian group, from the Upper Cretaceous Kallamedu
Formation of Cauvery Basin does indicate that even large animals were involved in the faunal exchange with Laurasia unless troodontids are proved to be Pangaean in distribution. Existence of shallow transTethyan connection between India and Eurasia in the Late Cretaceous was envisaged on the basis of common occurrence of Igdabatis indicus Prasad and Cappetta, 1993 in India and Spain (Soler-Gijón and LópezMartínez, 1998). Briggs (1989, 2003) suggested that close proximity of Greater India to Africa and Eurasia in the Late Cretaceous enabled free faunal interchanges between these landmasses (Fig. 5 B). Chatterjee and Scotese (1999), on the other hand, opined that the Late Cretaceous terrestrial link between Greater India and Greater Somalia accounts for the common occurrence of Gondwanan and Laurasian elements in the Late Cretaceous vertebrate fauna of India (Fig. 5C). Later Chatterjee and colleagues proposed a dispersal route between India and Africa via Oman-Kohistan-Ladakh Arc, a variant of Prasad and Sahni's (1999, 2009) island arc dispersal model, instead of biological connectivity through Greater Somalia (Chatterjee and Scotese, 2010, Chatterjee et al. 2013).

The sister group relationships of various Late Cretaceous vertebrate taxa of India and Madagascar even after > 20 Ma separation demands a sound explanation. Patriat and Segoufin (1988) had suggested a Late Cretaceous connection between Madagascar and India across the Seychelles Plateau and volcanic islands through which transoceanic dispersal were possible, a hypothesis supported later by Rage (1996). Using faunal similarity network analyses, Halliday et al. (2017) demonstrated close Late Cretaceous faunal similarities between India and Madagascar and suggested trans-oceanic dispersal of terrestrial and freshwater taxa between the two landmasses across a series of islands. While debunking the southern Kerguelen Plateau terrestrial route, Ali and Aitchison (2008) felt that the only possible link between India and Africa was through the Seychelles, Amirante Ridge, Providence Bank and Madagascar. Earlier, Averianov et al. (2003) reinterpreted the supposed marsupial tooth from the Late Cretaceous of Madagascar (Krause, 2001) as a zhelestid eutherian

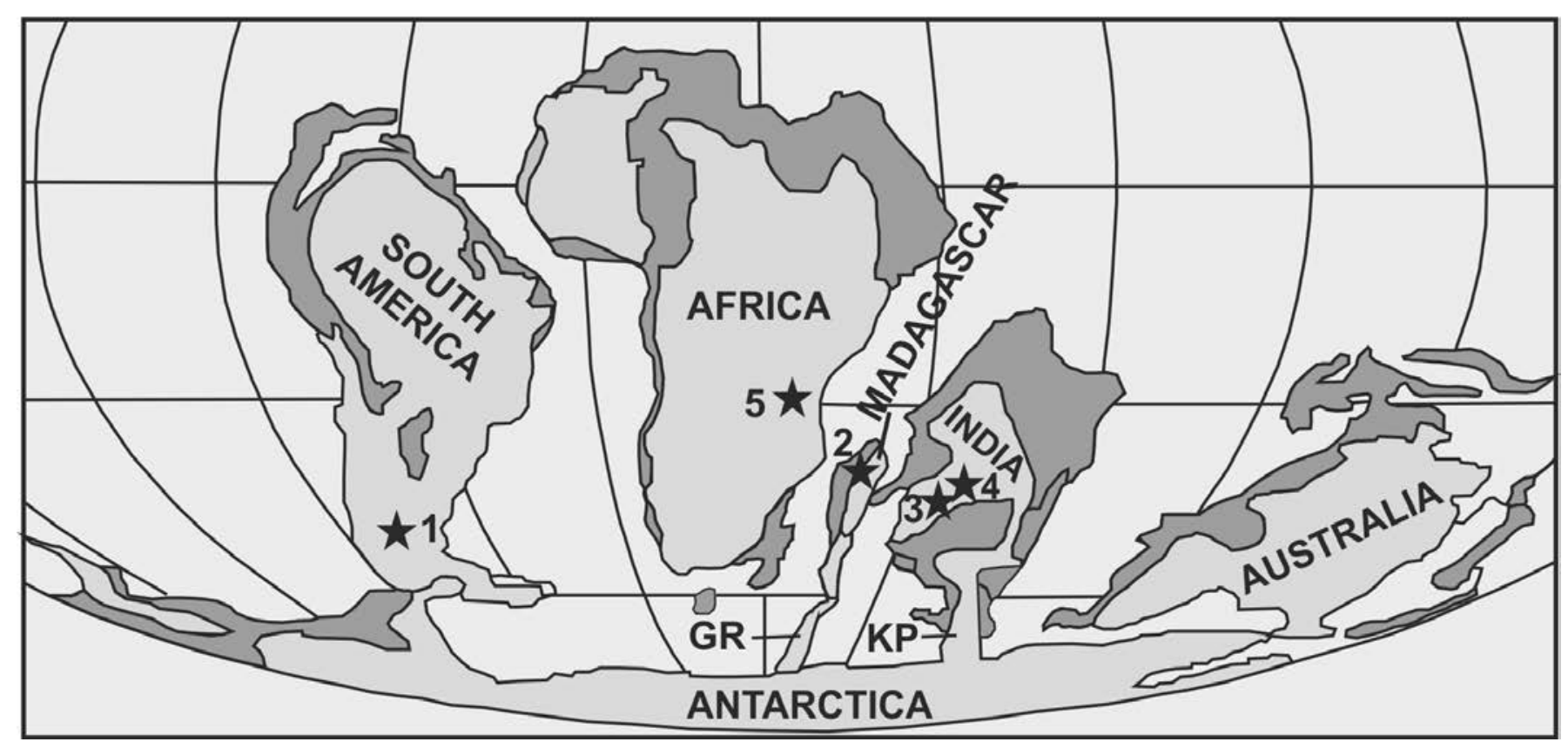

Figure 4. Palaeogeographic map of the southern continents in the Late Cretaceous depicting inferred terrestrial connection between Indo-Madagascar and South America via Antarctica and Kerguelen Plateau (KP) (Krause et al., 1997) or Gunnerus Ridge (GR) (Case, 2002). 1-5. Gondwanatherian mammal yielding sites. 

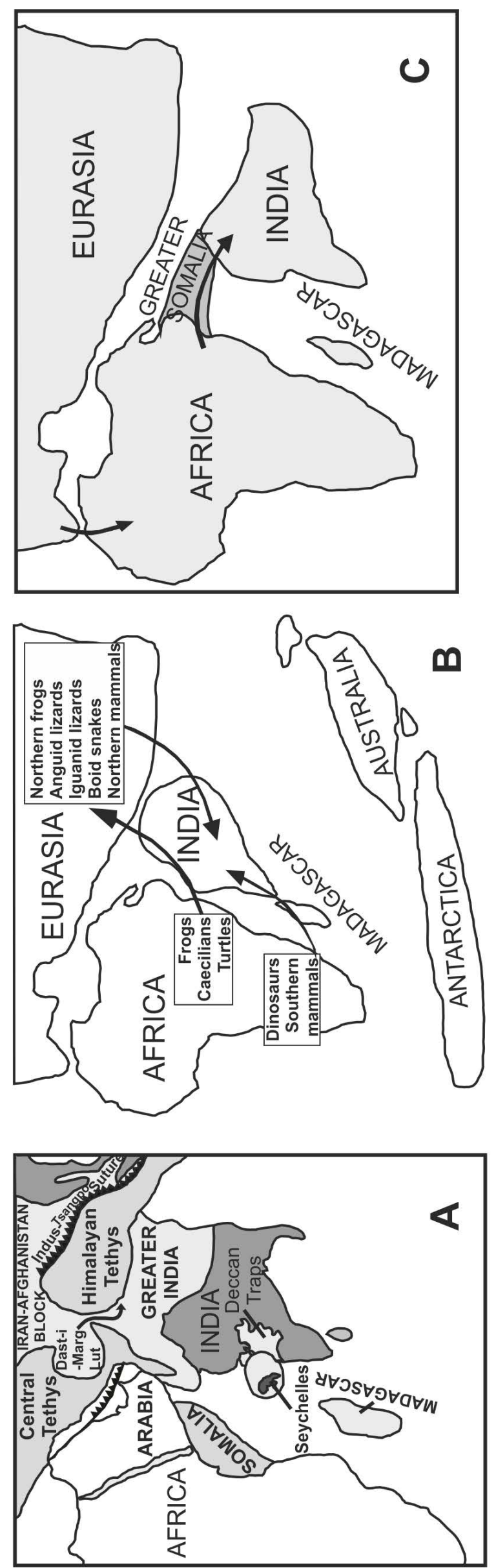

ำ

ปี

วิ

का 20

उ ลे

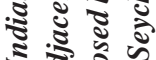

पัด จे

:ั้

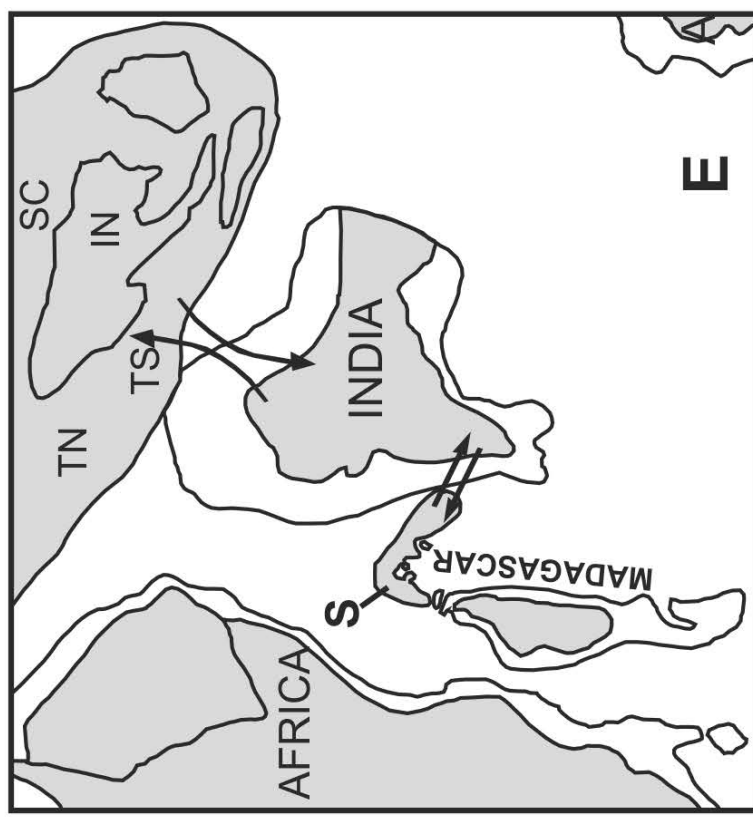

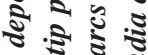

ชิ

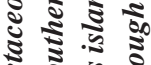

已ँ के है है

:

곤

ร 8 :

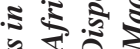

है

เิ

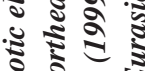

$\because$ ㅇํํ

ธิ ธิ

เ

ธิธี

ฐ

ธิ

है ปे

ธี छั

(ن)

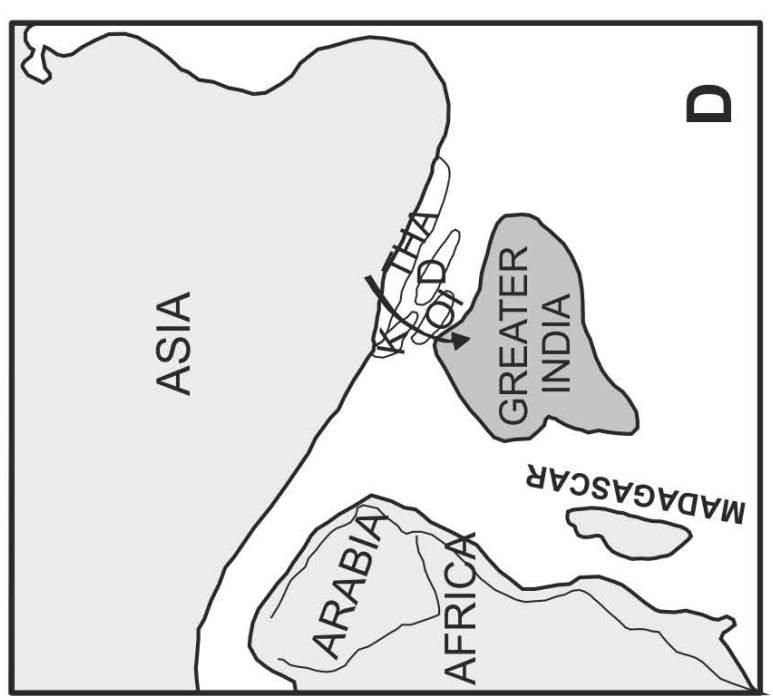

:

$\Xi 5$

ปิ ปี ช

ฐ

ธิ่)

\%

ब क

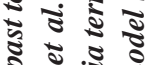

ะ

ป

इ के

วิ

돈

낭

ปั

हैं

ษั ชิ

ธิ ธิธ

ล)

s

क्षे

ฐิ

ถ

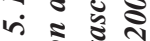

装星 
similar to Maastrichtian Lainodon (Gheerbrant and Astibia, 1999) from Spain and supported a terrestrial connection between Europe and Madagascar in the Late Cretaceous via Africa. An end Cretaceous terrestrial connection between Madagascar and Laurasia via India and the Seychelles Plateau was also envisaged on the basis of past and present distribution of iguanid lizards and boine snakes (Rage, 1996, 2003). In their review on the Mesozoic biogeographic history of Madagascar, Krause et al. (2019) also commented that some Late Cretaceous connections existed between Madagascar, India, Africa and Eurasia though the tectonic elements that made these connections possible are unknown at present. More recently, Torsvik et al. (2013) recognised a supposed microcontinent Mauritia and speculated on possible presence of a number of Precambrian microcontinental fragments in the Indian Ocean between Madagascar and India which are now concealed by the volcanic islands that track the

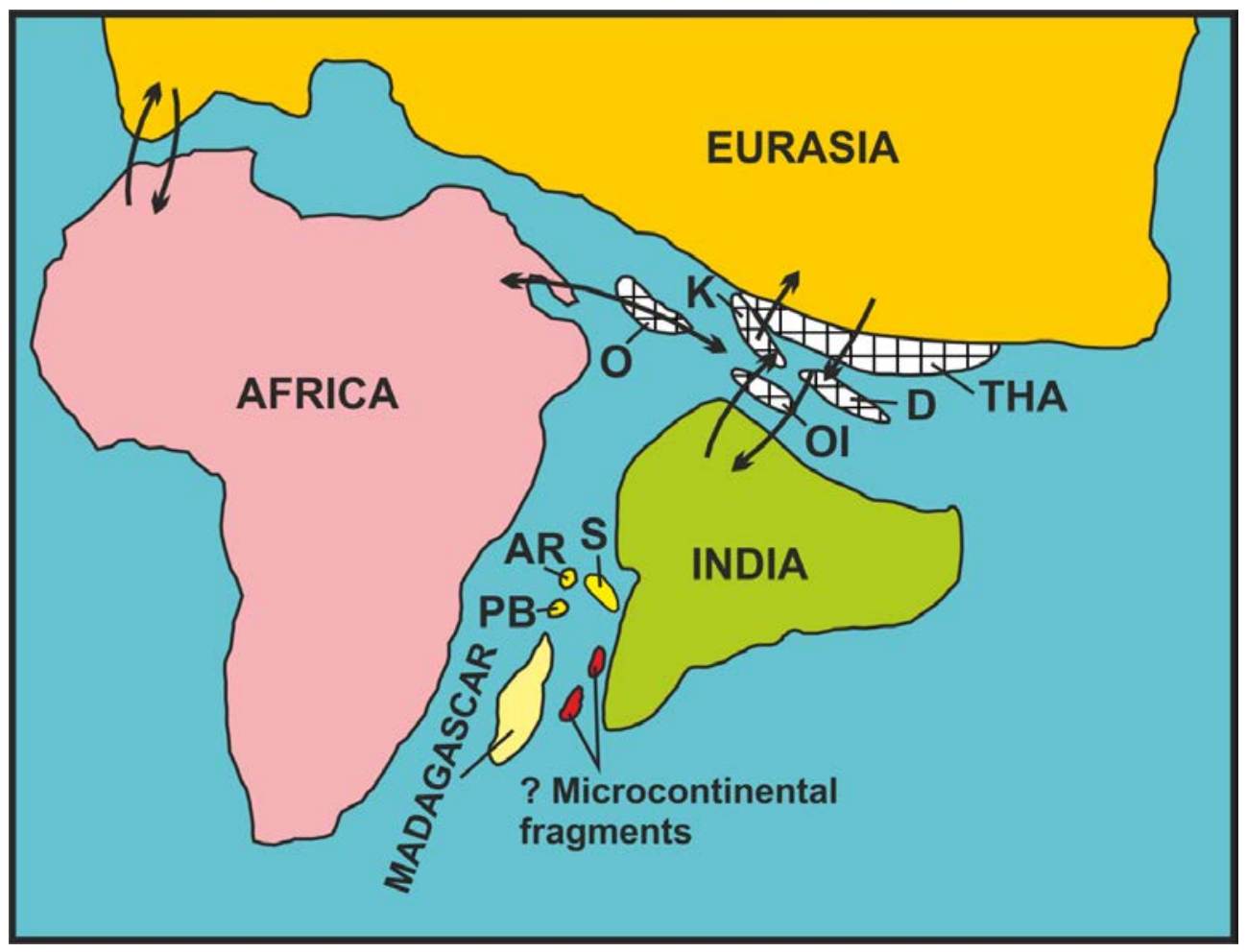

Figure 6. Proposed biotic dispersals between India and Eurasia using island arcs as 'stepping stones' and between India and Madagascar through the Seychelles, Amirante Ridge, Providence Bank and possibly some microcontinental fragments. Abbreviations: $A R=$ Amirante Ridge, $D=$ Dras Island Arc, $\mathrm{K}=$ Kohistan Island Arc, $\mathrm{O}=$ Oman Island Arc, $\mathrm{OI}=$ Oceanic Island, $\mathrm{PB}=$ Providence Bank, $S=$ the Seychelles Island, $T H A=$ Trans-Himalayan Arc.

northward drift of the Indian plate as it passed over the Réunion hotspot. The Laxmi Ridge, which lies to the north of the Seychelles microcontinent and buried beneath thick Indus Fan sediments, has been considered as a continental sliver isolated during the Seychelles/ India break-up (Bhattacharya et al., 1994; Collier et al., 2004). Prior to their burial by the oceanic basalts, these microcontinents along with the Seychelles Plateau, Amirante Ridge, Providence Bank may have formed important stepping stones between India and Madagascar allowing faunal interchanges between them (Fig. 6). On the other hand, the island arc systems and oceanic islands to the north of Greater India might have facilitated direct dispersal from the north or through Africa in the northwest (Fig. 6).

Yuan et al. (2018) using molecular phylogenies and divergence time estimates of Natatanura frogs of Madagascar also support the Indian plate as a 'Stepping Stone' for dispersals between Africa, Madagascar and Asia. They identify four time slices (between 130$88 \mathrm{Ma}$, 88-55 Ma, 55-25 Ma, 25-0 Ma) during which land bridges existed between these landmasses. According to this study, the first dispersal of Natatanuran frogs from its most common recent ancestor inhabiting Africa to India occurred at about $72 \mathrm{Ma}$, leading to the development of two endemic Indian families Ranixalidae and Micrixalidae. The endemic Madagascan Mantellidae with an Asian ancestry dispersed from Asia to Madagascar using India as a 'stepping stone’ around 62.4 Ma ago. More recently, Garg and Biju (2019) showed that, the endemic microhylid frogs from the Western Ghats having affinities with Southeast Asian forms used two land bridges, one at about $\sim 45.1 \mathrm{Ma}$ and the second one around $\sim 39.7 \mathrm{Ma}$, to colonize Southeast Asia. These dispersal events, interspersed with brief period of isolation, testify to periodic faunal interchanges between India and Asia prior to and during the suturing of these two landmasses. On the whole, the extant and fossil tetrapod fauna from the Upper Cretaceous deposits of India indicate close biogeographic connections between the Indian subcontinent, Madagascar, and Eurasia at a time when the former was suggested to be physically isolated from other landmasses.

\section{Summary}

Close examination of the Cretaceous vertebrate fauna reveal a complex biogeographic history for the Indian plate. The early-drift phase (i.e. Early Cretaceous) vertebrate fossil record of the Indian plate is poorly understood at present, but the limited data from the Karai Formation demonstrates a high latitude placement of the Indian plate. However, by the Campanian time, the vertebrate fauna becomes fully adapted to tropical to subtropical climate of the Tethyan realm. The better documented late-drift phase (i.e. Late Cretaceous) fossil record of India coming from the DVP and the Kallamedu Formation of the Cauvery Basin offers a wide range of biogeographic scenarios. Fossils from both DVP and the Cauvery Basin contain clades of both Gondwanan and Laurasian affinities. In addition to these, some endemic taxa that originated and evolved during India's long physical isolation and later dispersed out of India also co-existed. However, the fauna of Cauvery Basin is significantly different from the DVP fauna. The Upper Cretaceous Kallamedu fauna is taxonomically more similar to Madagascan forms despite the fact that geophysical data shows $>20$ Ma isolation of India from Madagascar following their break-up. The presence of various vertebrates showing Gondwanan and Laurasian affinities have been explained by different southern 
and northern dispersal models. Though a southern terrestrial route across Kerguelen Plateau and Antarctica was proposed in the past to explain the presence of taxa of Gondwanan affinities, it is found to be no more valid. Instead, the close phylogenetic relationships between the Late Cretaceous vertebrate clades of India and Madagascar favours land connections between these areas through the Seychelles, Amirante Ridge, Providence Bank and supposed currently buried microcontinental fragments. On the other hand, it is suggested that Laurasian elements of Indian Late Cretaceous vertebrate fauna used island-arc systems and oceanic islands to the north of Greater India as stepping stones to reach India directly or via Africa. In addition to this mode of dispersal, long distance rafting may have also played a significant role in the dispersal of small-sized animals between these landmasses. In the Late Cretaceous, Indian plate thus served as a stepping stone for the southern Gondwanan taxa to disperse out-ofIndia and the northern Laurasian taxa to reach Madagascar.

\section{Acknowledgements}

This paper has benefited from insightful comments by Prof. Ashok Sahni and Dr. Thomas John Dixon Halliday. L. Ranjit Singh is thanked for his help in drafting the figures of this manuscript. VP thanks Science and Engineering Research Board (SERB), New Delhi for financial support in the form of a major research project (EMR/2017/ 004143). GVRP acknowledges funding support from J.C. Bose National Fellowship SERB for this work.

\section{References}

Ali, J.R., and Aitchison, J.C., 2008, Gondwana to Asia: Plate tectonics, paleogeography and the biological connectivity of the Indian subcontinent from the Middle Jurassic through latest Eocene (166-35 Ma). Earth Science Reviews, v. 88, pp. 145-166.

Ali, J.R., and Aitchison, J.C., 2009, Kerguelen Plateau and the Late Cretaceous southern-continent bioconnection hypothesis: tales from a topographical ocean. Journal of Biogeography, v. 36, pp. 1778-1784.

Ali, J.R., and Krause, D.W., 2011, Late Cretaceous bioconnections between Indo-Madagascar and Antarctica: refutation of the Gunnerus Ridge causeway hypothesis. Journal of Biogeography, v. 38, pp. 1855-1872.

Ambwani, K., Sahni, A., Kar, R.K., and Dutta, D., 2003, Oldest known nonmarine diatoms (Aulacoseira) from the uppermost Cretaceous Deccan Intertrappean beds and Lameta Formation of India. Revue de Micropaléontologie, v. 46(2), pp. 67-71.

Anonymous, 1978, New dinosaurian remains. Geological Survey of India News, v. (5), pp. 4.

Archibald, J.D., 1996, Fossil evidence for a Late Cretaceous origin of "hoofed" mammals. Science, v. 272, pp. 1150-1153.

Averianov, A.O., Archibald, D., and Martin, T., 2003, Placental nature of the alleged marsupial from the Cretaceous of Madagascar. Acta Palaeontologica Polonica, v. 48(1), pp. 149-151.

Ayyasami, K., and Das, I., 1990, Unusual preservation of a Cretaceous turtle fossil. Journal of the Geological Society of India, v. 36, pp. 519-522.

Ayyasami, K., Elamparuthi, S., and Gowtham, B., 2016, An ichthyosaur vertebra from the Cretaceous (Middle Cenomanian) Karai Formation, southern India. Journal of the Geological Society of India, v. 8, pp. 706-708.

Baas, P., Manchester, S. R., Wheeler, E. A., and Srivastava, R., 2017, Fossil wood with dimorphic fibers from the Deccan Intertrappean
Beds of India - the oldest fossil Connaraceae? IAWA Journal, v. 38(1), pp. 124-133.

Bajpai, S., and Kapur, V.V., this volume, India's geodynamic evolution during the Eocene: perspectives on the origin and early evolution of modern mammal orders. Episodes, v. 43, pp. xxx- xxx

Baksi, S.K., 1972, Fossil fish from coastal Gondwana Raghavapuram Mudstone, West Godavari District, Andhra Pradesh, India. Proceedings of the Indian National Science Academy A, Physical Sciences, v. 38(1-2), pp. 32-44.

Bandyopadhyay, S., and Ray, S., this volume, Gondwana vertebrate faunas of India: Their diversity and intercontinental relationships. Episodes, v. 43, pp. xxx- xxx

Bhattacharya, G.C., Chaubey, A.K., Murty, G.P.S., Srinivas, K., Sarma, K.V.L.N.S., Subramanyam, V., and Krishna, K.S., 1994, Evidence for sea-floor spreading in the Laxmi Basin, northeastern Arabian Sea. Earth and Planetary Science Letters, v. 125, pp. 211-220.

Biju, S.D., and Bossuyt, F., 2003, New frog family from India reveals an ancient biogeographic link with the Seychelles. Nature, v. 425, pp. 711-714.

Blanford, H.F., 1862, On the Cretaceous and other rocks of South Arcot and Trichinopoly districts. Memoirs of the Geological Survey of India, v. 4, pp. 1-217.

Bonaparte, J.F., 1986, A new and unusual Late Cretaceous mammal from Patagonia. Journal of Vertebrate Paleontology, v. 6, pp. 264270.

Bossuyt, F., Brown, R.M., Hillis, D.M., Cannatella, D.C., and Milinkovitch, M.C., 2006, Phylogeny and biogeography of a cosmopolitan frog radiation: Late Cretaceous diversification resulted in continent-scale endemism in the family Ranidae. Systematic Biology, v. 55, pp. 579-594.

Bossuyt, F., and Milinkovitch, M.C., 2001, Amphibians as indicators of early Tertiary “Out-of-India” dispersal of vertebrates. Science, v. 292, pp. 93-95.

Briggs, J.C., 1989, The historic biogeography of India: isolation or contact? Systematic Biology, v. 38, pp. 322-332.

Briggs, J.C., 2003, The biogeographic and tectonic history of India. Journal of Biogeography, v. 30, pp. 381-388.

Case, J.A., 2002, A new biogeographic model for dispersal of Late Cretaceous vertebrates into Madagascar and India: Journal of Vertebrate Paleontology, Abstracts with Programs, v. 22(3), pp. 42A.

Chatterjee S., Goswami A., and Scotese, C.R., 2013, The longest voyage: Tectonic, magmatic and paleoclimatic evolution of the Indian plate during its northward flight from Gondwana to Asia. Gondwana Research, v. 23, pp. 238-267

Chatterjee, S., and Rudra, D.K., 1996, K/T events in India: impact, rifting, volcanism and dinosaur extinction. Memoirs of the Queensland Museum, 39(3), pp. 489-532.

Chatterjee, S., and Scotese, C.R., 1999, The breakup of Gondwana and the evolution and biogeography of the Indian plate. Proceedings of the Indian National Science Academy, v. 65A, pp. 397-425.

Chatterjee, S., and Scotese, C.R., 2010, The wandering Indian plate and its changing biogeography during the Late Cretaceous-Early Tertiary period. In: Bandyopadhyay, S. (Ed.), New Aspects of Mesozoic Biodiversity. Lecture Notes in Earth Science, v. 132, pp. 105-126, Springer-Verlag Berlin Heidelberg,

Chatterjee, S., Scotese, C.R., and Bajpai, S., 2017, The restless Indian plate and its epic voyage from Gondwana to Asia: its tectonic, paleoclimatic, and paleobiogeographic evolution. Geological Society of America, Special Paper 529, pp. 1-147.

Chenet A.-L., Courtillot V., Fluteau F., Gérard M., Quidelleur X., Khadri S.F.R., Subbarao, K.V. and Thordarson, T., 2009, Determination of rapid Deccan eruptions across the Cretaceous- 
Tertiary boundary using paleomagnetic secular variation: 2 . Constraints from analysis of eight new sections and synthesis for a $3500 \mathrm{~m}$ thick composite section. Journal of Geophysical Research, v.114, B06103.doi:10.1029/2008JB005644

Chenet, A.-L., Fluteau, F., Courtillot, V., Gérard, M., Quidelleur, X., and Subbarao, K.V., 2008, Determination of rapid Deccan eruptions across the Cretaceous-Tertiary boundary using paleomagnetic secular variation: Results from a 1200 m thick section in the Mahabaleshwar escarpment. Journal of Geophysical Research, v.113, B04101.doi:10.1029/2006JB0046

Chenet A.-L., Quidelleur, X., Fluteau, F., Courtillot, V., and Bajpai, S., 2007, ${ }^{40} \mathrm{~K}-{ }^{40} \mathrm{Ar}$ dating of the main Deccan large igneous province; further evidence of KTB age and short duration. Earth and Planetary Science Letters, v. 263, pp. 1-15.

Collier, J.S., Minshull, T.A., Kendall, J.-M., Whitmarsh, R.B., Rümpker, G., Joseph, P., Samson, P., Lane, C.I., Sansom, V., Vermeesch, P.M., Hammond, J., Wookey, J., Teanby, N., Ryberg, T.M., and Dean, S.M., 2004, Rapid continental break-up and microcontinent formation in the western Indian Ocean. Eos, v. 85(46), 481-496.

Conti, E., Eriksson, T., Schönenberger, J., Sytsma, K.J., and Baum, D.A., 2002, Early Tertiary out-of-India dispersal of Crypteroniaceae: evidence from phylogeny and molecular dating. Evolution, v. 56, pp. 1931-1942

Cooper, A., La1ueza-Fox, C., Anderson, S., Rambaut, A., Austin, S., and Ward, R., 2001, Complete mitochondrial genome sequences of two extinct moas clarify ratite evolution. Nature, v. 409, pp. 704-707.

Das Sarma, D.C., and Sinha, N.K., 1966, On the occurrence of shark teeth and other marine fossils in the Nimar Sandstone horizon of the Bagh Beds. Indian Minerals, v. 20(1), pp. 110-111.

De Lapparent de Broin, F., and Prasad, G.V.R., in press, Chelonian Pelomedusoides remains from the Late Cretaceous of Upparhatti (southwestern India): Systematics and paleobiogeographical implications. In: Prasad, G.V.R., and Patnaik, R. (Eds.), Biological Consequences of Plate Tectonics: New Perspectives on postGondwanaland Break-up. Springer, Cham, Switzerland, pp. xxx$\mathrm{xxx}$ ).

Dhiman, H., Prasad, G.V.R., and Goswami, A., 2018, Parataxonomy and palaeobiogeographic significance of dinosaur eggshell fragments from the Upper Cretaceous strata of the Cauvery Basin, South India. Historical Biology, doi: 10.1080/08912963.2018. 1450408

Dhiman, H., Verma, V., and Prasad, G.V.R.,2017, Preliminary study of structure and taphonomy of dinosaur eggs and nests of the Upper Cretaceous Lameta Formation near Padlya, Lower Narmada Valley, India. In: Kathal, P.K., Nigam, R., and Talib., A. (Eds.), Advanced Micropaleontology. Scientific Publishers, New Delhi, pp. 212-232.

Egerton, P.M.G., 1845, On the remains of fishes found by Mr. Kaye and Mr. Cunliffe in The Pondicherry Beds. The Quarterly Journal of the Geological Society of London, v. 1, pp. 164-171.

Fernández, M.S., and Khosla, A., 2015, Parataxonomic review of the Upper Cretaceous dinosaur eggshells belonging to the Oofamily Megaloolithidae from India and Argentina. Historical Biology, v. 27, pp. 158-180.

Gaffney, E.S., Chatterjee, S., and Rudra, D.K., 2001, Kurmademys, a new side-necked Turtle (Pelomedusoides: Bothremydidae) from the Late Cretaceous of India. American Museum Novitates, v. 3321, pp. 1-16.

Gaffney, E.S., Krause, D.W., and Zalmout, I.S., 2009, Kinkonychelys, a new side-necked turtle (Pelomedusoides: Bothremydidae) from the Late Cretaceous of Madagascar. American Museum Novitates, v. 2009 (3662), pp. 1-25.
Galton, P.M., and Ayyasami, K., 2017, Purported latest bone of a plated dinosaur (Ornithischia: Stegosauria), a “dermal plate” from the Maastrichtian (Upper Cretaceous) of southern India. Neues Jahrbuch für Geologie und Paläontologie - Abhandlungen, v. 285(1), pp. 91-96. doi:10.1127/njgpa/2017/0671

Garg, S., and Biju, S.D., 2019, New microhylid frog genus from peninsular India with southeast affinity suggests multiple Cenozoic biotic exchanges between India and Eurasia. Scientific Reports, v. 9: 1906. doi.org/10.1038/s41598-018-38133-x.

Gheerbrant, E., and Astibia, H., 1999, The Upper Cretaceous mammals from Laño (Spanish Basque Country). Estudios del Museo de Ciencias naturales de Alava, v. 14, pp. 295-323

Goswami, A., Prasad, G.V.R., Benson, R.B., Verma, O., and Flynn, J. J., 2012, New vertebrates from the Late Cretaceous Kallamedu Formation, Cauvery Basin, South India, including a troodontid dinosaur, a gondwanatherian mammal, and a Simosuchus-like notosuchian crocodyliform. Journal of Vertebrate Paleontology, Abstract v. 32A, pp. 102.

Goswami A., Prasad G.V.R., Upchurch P., Boyer D.M., and Seiffert, E.R., Verma O., Gheerbrant E., and Flynn J.J., 2011, A radiation of arboreal basal eutherian mammals beginning in the Late Cretaceous of India. Proceedings of the National Academy of Sciences, USA, v. 108, pp. 16333-16338.

Goswami, A., Prasad, G.V.R., Verma, O., Flynn, J.J., and Benson, R.B.J., 2013, A troodontid dinosaur from the latest Cretaceous of India. Nature Communications, 4, pp. 1-5.

Gowda, S.S., 1967, On a new fossils fish known from an otolith from the south Indian Cenomanian. Journal of the Geological Society of India,v. 8, pp. 119-129.

Gower, D.J., Kupfer, A., Oommen, O.V., Himstedt, W., Nussbaum. R.A., Loader, S.P., Presswell, B., Muller, H., Krishna, S.B., Boistel, R., and Wilkinson, M., 2002, A molecular phylogeny of ichthyophiid caecilians (Amphibia: Gymnophiona: Ichthyophiidae): Out of India or out of South East Asia? Proceedings of the Royal Society London, v. 269, pp. 15631569.

Hahn, G., and Hahn, R., 2003, New multituberculate teeth from the Early Cretaceous of Morocco. Acta Palaeontologica Polonica, v. 48, pp. 349-356.

Halliday, T.J.D., Cuff, A.R., Prasad, G.V.R., Thanglemmoi, M.S., and Goswami, A., 2016, New record of Egertonia (Elopiformes, Phyllodontidae) from the Late Cretaceous of South India. Papers in Palaeontology, v. 2, pp. 287-294.

Halliday, T.J.D., Prasad, G.V.R., and Goswami, A., 2017, Faunal similarity in Madagascan and South Indian Late Cretaceous vertebrate faunas. Palaeogeography, Palaeoclimatology, Palaeoecology, v. 468(2), pp. 70-75.

Hay, W.W., DeConto, R.M., Wold, C.N., Wilson, K.M., Voigt, S., Schulz, M., Wold, A.R., Dullo, W.-C., Ronov, A.B., Balukhovsky, A.N., and Söding, E., 1999, Alternative global Cretaceous paleogeography. Geological Society of America Special Paper 332, pp. 1-47.

Heinrich, W.-D., 1999, First haramiyid (Mammalia, Allotheria) from the Mesozoic of Gondwana. Mitteilungen aus dem Museum für Naturkunde in Berlin, Geowissenschatliche Reihe, v. 2, pp. 159170.

Hone, D.W.E., Farke, A.A., and Wedel, M.J., 2016, Ontogeny and the fossil record: What, if anything, is an adult dinosaur. Biological Letters, v. 12, pp. 1-8. doi.org/10.1098/rsbl.2015.0947

Jaeger, J.J., Courtillot, V., and Tapponnier, P., 1989, Palaeontological view of the ages of the Deccan Traps, the CretaceousTertiary boundary, and the India-Asia collision. Geology, v. 17, pp. 316-319.

Jaitly, A.K., and Ajane, R., 2013, Comments on Placenticeras mintoi 
(Vredenburg, 1906) from the Bagh Beds (Late Cretaceous), Central India with special reference to Turonian Nodular Limestone horizon. Journal of the Geological Society of India v. 81, pp. 565-5674.

Jay, A.E., Mac Niocaill, C., Widdowson, M., Self, S., and Tuner, W., 2009, New palaeomagnetic data from the Mahabaleshwar Plateau, Deccan flood basalt province, India: Implications from the volcanostratigraphic architecture of continental flood basalt provinces. Journal of the Geological Society, v. 166, pp. 13-24.

Jay, A.E., and Widdowson, M., 2008, Stratigraphy, structure and volcanology of the south-east Deccan continental flood basalt province: Implications for eruptive extent and volumes. Journal of the Geological Society, v. 165, pp. 177-188.

Kamei, R.G., Mauro, D.S., Gower, D.J., Van Bocxlaer, I., Sherratt, E., Thomas, A., Babu, S., Bossuyt, F., Wilkinson, M.,and Biju, S.D., 2012, Discovery of a new family of amphibians from northeast India with ancient links to Africa. Proceedings of the Royal Society B, Biological Sciences, v. 279 (1737), pp. 23962401.

Kent, R.W., Pringle, M.S., Müller, R.D., Saunders, A.D., and Ghose, N.C., 2002, ${ }^{40} \mathrm{Ar} /{ }^{39} \mathrm{Ar}$ Geochronology of the Rajmahal Basalts, India, and their Relationship to the Kerguelen Plateau. Journal of Petrology, v. 43(7), pp. 1141-1153.

Khosla, A., Kapur, V.V., Sereno, P.C., Wilson, J.A., Wilson, G.P., Dutheil, D., Sahni, A., Singh, M.P., Kumar, S., and Rana, R.S., 2003, First dinosaur remains from the Cenomanian-Turonian Nimar Sandstone (Bagh Beds), District Dhar, Madhya Pradesh, India. Journal of the Palaeontological Society of India, v. 48: 115-127

Kohring, R., Bandel, K., Kortum, D., and Parthasararthy, S., 1996, Shell structure of a dinosaur egg from the Maastrichtian of Ariyalur (Southern India). Neues Jahrbuch für Geologie und Paläontologie, Monatshefte, v. 1, pp. 48-64.

Krause, D.W., 2001, Fossil molar from a Madagascan marsupial. Nature, v. 412, pp. 497-498.

Krause, D.W., Gottfried, M.D., O’connor, P.M., and Roberts, E.M., 2003, A Cretaceous mammal from Tanzania. Acta Palaeontologica Polonica, v. 48, pp. 321-330.

Krause, D.W., and Maas, M.C., 1990, The biogeographic origins of late Paleocene-early Eocene mammalian immigrants to the Western Interior of North America. In: Bown, T.M., and Rose, K.D. (Eds.), Dawn of the Age of Mammals in the Northern Part of the Rocky Mountain Interior, North America. Geological Society of America Special Paper 243, pp. 71-106,

Krause, D.W., O’Connor, P.M., Curry Rogers, K., Sampson, S.D., Buckley, G.A., and Rogers, R.R., 2006, Late Cretaceous terrestrial vertebrates from Madagascar: Implications for Latin American biogeography. Annals of the Missouri Botanical Gardens, v. 93, pp. 178-208.

Krause, D.W., Prasad, G.V.R., Koenigswald, W.V., Sahni A., and Grine, F.E., 1997, Cosmopolitanism among Gondwanan Late Cretaceous mammals. Nature, v. 390, pp. 504-507.

Krause, D.W., Sertich, J.J.W., O’Connor, P.M., Rogers, K.C., and Rogers, R.R., 2019, The Mesozoic biogeographic history of Gondwanan terrestrial vertebrates: Insights from Madagascar's fossil record. Annual Review of Earth and Planetay Sciences, v. 47, pp. 519-553.

Kurabayashi, A., Sumida, M., Yonekawa, H., Glaw, F., Vences, M., and Hasegawa, M., 2008, Phylogeny, recombination, and mechanisms of stepwise mitochondrial genome reorganization in mantellid frogs from Madagascar. Molecular Biology and Evolution, v. 25, pp. 874-891.

Lawver, L.A., Roger, J.Y., Sandwell, D.T., and Scotese, C.R., 1991. Evolution of the Antarctic continental margins. In: Thomson,
M.R., Crame, J.A., Thomson, J.W. (Eds.). The Geological Evolution of Antarctica. Cambridge University, Cambridge, pp. 533-539.

Lydekker, R., 1879, Indian pre-Tertiary Vertebrata. Part 3. Fossil Reptilia and Batrachia. Palaeontolgia Indica, Series 4, 1, pp. 2033.

Lydekker, R., 1888, Note on the classification of the Ichthyopterygia with a notice of two new species. Geological Magazine, 3rd Series 5, pp. 309-314.

Macey, J.R., Schulte II, J.A., Larson, A., Ananjeva, N.B., Wang, Y., Pethiyagoda, R., Rastegar-Pouyani., and Papenfuss, T.J., 2000, Evaluating trans-Tethys migration: an example using acrodont lizard phylogenetics. Systematic Biology, v. 49(2), pp. 233-256

Maidment, S.C.R., Norman, D.B., Barrett, P.M., and Upchurch, P., 2008,. Systematics and phylogeny of Stegosauria (Dinosauria: Ornithischia). Journal of Systematic Palaeontology, v. 6, pp. 367407.

Manchester, S.R., Kapgate, D.K., and Wen, J., 2013, Oldest fruits of the grape family (Vitaceae) from the Late Cretaceous Deccan cherts of India. American Journal of Botany, v. 100(9), pp. 18491859.

Matley, C.A., 1929, The Cretaceous dinosaurs of the Trichinopoly District, and the rocks associated with them. Records of the Geological Survey of India, v. 61(4), pp. 337-349.

Misra, K.S., and Saxena, R.S., 1964, A new fossil fish, Jhingrania roonwali, from the Rajmahal Hills, India. Journal of the Palaeontological Society of India, v. 4, pp. 30-34.

Mohabey, D.M., Head, J.J., and Wilson, J.A., 2011, A new species of the snake Madtsoia from the Upper Cretaceous of India and its paleobiogeographic implications. Journal of Vertebrate Paleontology, v. 31, pp. 588-595.

Novas, F.E., Chatterjee, S., Rudra, D.K., and Datta, P.M., 2010, Rahiolisaurus gujaratensis n. gen. n. sp., a new abelisaurid theropod from the Late Cretaceous of India. In: Bandhyopadhyay, S. (Ed.), New Aspects of Mesozoic Biodiversity. Lecture Notes in Earth Sciences, v. 132, pp. 45-62, Springer-Verlag Berlin Heidelberg.

Patriat, P., and Segoufin, J., 1988, Reconstruction of the Central Indian Ocean. Tectonophysics, v. 155, pp. 211-234.

Paul, S.N., 1973, A note on the fossil shark tooth from Tiruchchirappalli District, Tamil Nadu, India. Current Science, v. 42(21), pp. 753.

Pereda-Suberbiola, X., Díaz-Martínez, I., Salgado, L., and Valais, S. De., 2015, Síntesis del registro fósil de dinosaurios tireóforos en Gondwana. Argentinian Paleontological Association Publication Electronica, v. 15(1), pp. 90-107.

Powell, C.McA., 1979, A speculative tectonic history of Pakistan and its surrounding: Some constraints from the Indian Ocean. In: Farah, A., and Dejong, K.(Eds.), Geodynamics of Pakistan, Geological Survey of Pakistan, Quetta, pp. 5-24.

Prasad, G.V.R., 2012, Vertebrate biodiversity of the Deccan volcanic province of India: A review. Bulletin de la Société géologique de France, v. 183, pp. 597-610.

Prasad, G.V.R., and de Broin, F., 2002, Late Cretaceous crocodile remains from Naskal (India): Comparisons and biogeographic affinities. Annales de Paléontologie, v. 88(1), pp. 19-71.

Prasad, G.V.R., and Cappetta, H., 1993, Late Cretaceous selachians from India and the age of the Deccan Traps. Palaeontology, v. 36, pp. 231-248.

Prasad, G.V.R., Jaeger, J.-J., Sahni, A., Gheerbrant, E., and Khajuria, C.K., 1994, Eutherian mammals from the Upper Cretaceous (Maastrichtian) intertrappean beds of Naskal, Andhra Pradesh, India. Journal of Vertebrate Paleontology, v. 14, pp. 260-277.

Prasad, G.V.R., Manhas, B.K., and Arratia, G., 2004, Elasmobranch 
and actinopterygian remains from the Jurassic and Cretaceous of India. In: Arratia, G., and Tintori, A. (Eds.), Mesozoic Fishes 3 Systematics, Paleoenvironments and Biodiversity. Verlag Dr. Friedrich Pfeil, Munchen, pp. 625-638.

Prasad, G.V.R., Pandey, D.K., Alberti, M., Fürsich, F.T., Thakkar, M.G., and Chauhan, G.D., 2017a, Discovery of the first ichthyosaur from the Jurassic of India: Implications for Gondwanan palaeobiogeography. PLoS ONE 12(10): e0185851. doi.org/10.1371/journal.pone.0185851

Prasad, G.V.R., and Rage, J.-C., 1991, A discoglossid frog in the latest Cretaceous (Maastrichtian) of India. Further evidence for a terrestrial route between India and Laurasia in the latest Cretaceous. Comptes rendus de l'Académie des Sciences, Paris, v. 313, pp. 273-278.

Prasad, G.V.R., and Rage, J.-C., 1995, Amphibians and squamates from the Maastrichtian of Naskal, India. Cretaceous Research, v. 16 , pp. 95-107.

Prasad, G.V.R., and Rage, J.-C., 2004, Fossil frogs (Amphibia: Anura) from the Upper Cretaceous intertrappean beds of Naskal, Andhra Pradesh. Revue de Paléobiologie, v. 23(1), pp. 99-116.

Prasad, G.V.R., and Sahni, A., 1988, First Cretaceous mammal from India. Nature, v. 332, pp. 638-640.

Prasad, G.V.R., and Sahni, A., 1999, Were there size constraints on biotic exchanges during the northward drift of the Indian plate? Proceedings of the Indian National Science Academy, v. 65A, pp. 377-396.

Prasad, G.V.R., and Sahni, A., 2009, Late Cretaceous continental vertebrate fossil record from India: palaeobiogeographical insights. Bulletin de la Société géologique de France, v. 180, pp. 369-381.

Prasad, G.V.R., Verma, O., Flynn, J.F., and Goswami, A., 2013, A new Cretaceous vertebrate fauna from the Cauvery basin, South India: implications for Gondwana paleobiogeography. Journal of Vertebrate Paleontology, v. 33, pp.1260-1268.

Prasad, G.V.R., Verma, O., Gheerbrant, E., Goswami, A., Khosla, A., Parmar, V., and Sahni, A., 2010, First mammal evidence from the Late Cretaceous of India for biotic dispersal between India and Africa at the K/T transition. Comptes Rendus Palevol, v. 9, pp. 63-71.

Prasad, G.V.R., Verma, O., Sahni, A., Krause, D.W., Khosla, A., and Parmar, V., 2007a, A new Late Cretaceous Gondwanatherian mammal from Central India. Proceedings of the Indian National Science Academy, v. 73(1), pp. 17-24.

Prasad, G.V.R., Verma, O., Sahni, A., Parmar, V., Khosla, A., 2007b, A Cretaceous hoofed mammal from India. Science, v. 318, pp. 937.

Prasad, G.V.R., Verma, V., Grover, P., Priyadarshini, R., Sahni, A., and Lourembam, R.S., 2016, Isolated Archosaur teeth from the green sandstone capping the Coralline Limestone (Bagh Group) of the Narmada valley: Evidence for the presence of pre-Late to Late Maastrichtian abelisaurids in India. Island Arc. 2016 doi: 10.1111/iar.12142

Prasad, G.V.R., Verma, V., Sahni, A., Lourembam, R.S., and Rajkumari, P., 2017b, Elasmobranch fauna from the upper most part of the Cretaceous Bagh Group, Narmada valley, India. Island Arc 2017; e12200. doi.org/10.1111/iar.12200

Prasad, V., Stromberg, C.A.E., Alimohammadian, H., and Sahni, A., 2005, Dinosaur coprolites and the early evolution of grasses and grazers. Science, v. 310, pp. 1177-1180.

Prasad, V., Strömberg, C.A.E., Leaché, A.D., Samant, B., Patnaik, R., Tang, L., Mohabey, D.M., Ge, S., and Sahni, A., 2011, Late Cretaceous origin of the rice tribe provides evidence for early diversification in Poaceae. Nature Communications, v. 2, Article No. 480.doi: 10.1038/ncomms1482
Pritchard, A.C., McCartney, J.A., Krause, D.W., and Kley, N.J., 2014, New snakes from the Upper Cretaceous (Maastrichtian) Maevarano Formation, Mahajanga Basin, Madagascar. Journal of Vertebrate Paleontology, v. 34(5), pp. 1080-1093.

Rage, J.-C., 1996, Le peuplement animal de Madagascar: une composante venue de Laurasie est-elle envisageable? In: Lourenco, W.R. (Ed.), Editions de I’ORSTOM, Paris, Biogéographie de Madagascar, pp. 27-35.

Rage, J.-C., 2003, Relationships of the Malagasy fauna during the Late Cretaceous: Northern or southern routes? Acta Palaeontologica Polonica, v. 48, pp. 661-662.

Rage, J.-C., and Prasad, G.V.R., 1992, New snakes from the Late Cretaceous (Maastrichtian) of Naskal, India. Neues Jahrbuch für Geologie und Paläontologie, v. 187, pp. 83-97.

Rage, J.-C., Prasad, G.V.R., Bajpai, S., 2004, Additional snakes from the Uppermost Cretaceous (Maastrichtian) of India. Cretaceous Research, v. 25, pp. 425-434.

Rage, J.-C., Prasad, G.V.R., Verma, O., Khosla, A., and Parmar, V., in press, Anuran lissamphibian and squamate reptiles from the Upper Cretaceous (Maastrichtian) Deccan intertrappean sites in Central India, with a review of lissamphibian and squamate diversity in the northward drifting Indian plate. In: Prasad, G.V.R., and Patnaik, R. (Eds.), Biological Consequences of Plate Tectonics: New Perspectives on post-Gondwanaland Break-up. Springer, Cham, Switzerland, pp. Xxx-Xxx.

Rana, R.S., and Wilson, G.P., 2003, New Late Cretaceous mammals from the intertrappean beds of Rangapur, India and paleobiogeographic framework. Acta Palaeontologica Polonica, v. 48, pp. 331-348.

Sahni, A., 1984, Cretaceous-Palaeocene terrestrial faunas of India: lack of faunal endemism during drifting of the Indian plate. Science, v. 226, pp. 441-443.

Sahni, M.R., 1957, A fossil reptilian egg from the Uttaturs (Cenomanian) of southern India, being the first record of a vertebrate fossil egg in India. Records of the Geological Survey of India, v. 87, pp. 671-674.

Sastry, M.V.A., Acharyya, S.K., Shah, S.C., Satsangi, P.P., Ghosh, S.C., Raha, P.K., Singh, G., and Ghosh, R.N., 1977, Stratigraphic lexicon of Gondwana formations of India. Geological Survey of India, Miscellaneous Publications, v. 36, pp.1-170.

Schoene, B., Samperton, K.M., Eddy, M.P., Keller, G., Adatte, T., Bowring, S.A., Khadri, S.F.R., and Gertsch, B., 2015, U-Pb geochronology of the Deccan Traps and relation to the endCretaceous mass extinction. Science, v. 347, pp. 182-184.

Scillato-Yane, G.J., and Pascual, R., 1984, Un peculiar Paratheria, Edentata (Mammalia) del Paleoceno de Patagonia. Primeras Jornada Argentinas de Paleontología de Vertebrados, Resumenes, Abstract 16, pp. 15.

Sigogneau-Russell, D., 1991, First evidence of Multituberculata (Mammalia) in the Mesozoic of Africa. Neues Jahrbuch für Geologie und Paläontologie Monatshefte, v. 2, pp. 119-125.

Smith, T., Bast, E.D., and Sigé, B., 2010, Euarchontan affinity of Paleocene Afro- European adapisoriculid mammals and their origin in the late Cretaceous Deccan Traps of India. Naturwissenschaften, v. 97, pp. 417-422.

Soler-Gijón, R., and López-Martínez, N., 1998. Sharks and rays (Chondrichthyes) from the Upper Cretaceous red beds of the south-central Pyrenees (Lleida, Spain): Indices of an India-Eurasia connection. Palaeogeography, Palaeoclimatology, Palaeoecology, v. 141, pp. 1-12.

Sparks, J.S., 2004, Molecular phylogeny and biogeography of the Malagasy and South Asian cichlids (Teleostei: Perciformes: Cichlidae): Molecular Phylogenetics and Evolution, v. 30, pp. 599-614. 
Srivastava, R., Srivastava, G., and Dilcher, D.L., 2014, Coryphoid palm leaf fossils from the Maastrichtian -Danian of Central India with remarks on phytogeography of the Coryphoidae (Arecaceae). PLoS ONE 9(11): e111738.doi: 10.1371/ journal. pone.0111738.

Stoliczka, F., 1873, Cretaceous fauna of southern India. Memoirs of the Geological Survey of India, Palaeontologia India, v. 4, pp. 66-69.

Storey M., Mahoney J.J., Saunders A.D., Duncan R.A., Kelley S.P., and Coffin M.F., 1995, Timing of hot spot-related volcanism and the break-up of Madagascar India. Science, v. 267, pp. 852-855.

Sundaram, R., Henderson, R.A., Ayyasami, K., and Stilwell, J.D., 2001, A lithostratigraphic revision and palaeoenvironmental assessment of the Cretaceous System exposed in the onshore Cauvery Basin, southern India. Cretaceous Research, v. 22, pp. 743-762.

Torsvik, T.H., Amundsen, H., Hartz, E.H., Corfu, F., Kusznir, N., Gaina, C., Dubrovine, P.V., Steinberger, B., Ashwal, L.D., and Jamtveit, B., 2013, A Precambrian microcontinent in the Indian Ocean. Nature Geoscience, v. 6, pp. 223-227.

Tortosa, T., Buffetaut, E., Vialle, N., Dutour, Y., Turini, E., and Cheylan, G., 2014, A new abelisaurid dinosaur from the Late Cretaceous of southern France: palaeobiogeographical implications. Annales de Paléontologie, v. 100(1), pp. 63-86.

Underwood, C.J., Goswami, A., Prasad, G.V.R., Verma, O., and Flynn, J.J., 2011, Marine vertebrates from the 'middle' Cretaceous (Early Cenomanian) of South India. Journal of Vertebrate Paleontology, v. 31(3), pp. 539-552.

Upchurch, P., Barrett, P.M., and Dodson, P., 2004, Sauropoda. In: Weishampel, D.B., Dodson, P., and Osmólska, H. (Eds.), The Dinosauria (2nd edition). University of California, Berkeley, pp. 259-322.

Van der Meijden, A., Vences, M., Hoegg, S., Boistel, R., Channing, A., and Meyer, A., 2007, Nuclear gene phylogeny of narrowmouthed toads (Family: Microhylidae) and a discussion of competing hypotheses concerning their biogeographicalorigins. Molecular Phylogenetics and Evolution, v. 44, pp. 1017-1030.

Veevers, J.J., Powell, C. McA, and Roots, D., 1991, Review of seafloor spreading around Australia, I: synthesis of the pattern of spreading. Australian Journal of Earth Sciences, v. 38, pp. 415-433.

Verma, K.K., 1965, On fossil shark teeth from the Bagh beds of Amba Dongar area, Gujarat State. Current Science, v. 34, pp. 289-290.

Verma, O., 2015, Cretaceous vertebrate fauna of the Cauvery Basin, southern India: Palaeodiversity and palaeobiogeographic implications. Palaeogeography, Palaeoclimatology, Palaeoecology, v. 431, pp. 53-67.

Verma, O., Prasad, G.V.R., Goswami, A., and Parmar, V., 2012, Ptychodus decurrens Agassiz (Elasmobranches: Ptychodonditae) from the Upper Cretaceous of India. Cretaceous Research, v. 33, pp. 183-188.

Whatley, R.C., 2012, The ‘Out of India’ hypothesis: Further supporting evidence from the extensive endemism of Maastrichtian non marine ostracoda from the Deccan volcanic region of peninsular India. Revuede Paléobiologie, v. 11, pp. 229-248.

Whatley, R.C., and Bajpai, S., 2006, Extensive endemism among the Maastrichtian nonmarine Ostracoda of India with implications for palaeobiogeography and "out of India" dispersal. Revista Española de Micropaleontología, v. 38(2-3), pp. 229-244.

Wilson, J.A., Barrett, P.M., and Carrano, M.T., 2011, An associated partial skeleton of Jainosaurus cf. septentrionalis (Dinosauria: Sauropoda) from the Late Cretaceous of Chhota Simla, Central India. Palaeontology, v. 54 (5), pp. 981-998.

Wilson, J.A., Mohabey, D.M., Peters, S.E., and Head, J.J., 2010, Predation upon hatchling dinosaurs by a new snake from the Late Cretaceous of India. PLoS Biology 8(3): e1000322. https:// doi.org/10.1371/journal.pbio.1000322

Wilson J.A., Sereno P.C., Srivastava S., Bhatt D.K., Khosla A., and Sahni A., 2003, A new abelisaurid (Dinosauria, Theropoda) from the Lameta Formation (Cretaceous, Maastrichtian) of India. Contributions from the Museum of Paleontology, University of Michigan, v. 31(1), pp. 1-42.

Yadagiri, P., and Ayyasami, K., 1979, A new stegosaurian dinosaur from Upper Cretaceous sediments of south India. Journal of the Geological Society of India, v. 20(11), pp. 521-530.

Yadagiri, P., and Ayyasami, K., 1989, A carnosaurian dinosaur from the Kallamedu Formation (Maastrichtian horizon), Tamil Nadu. In: Sastry, M.V.A., Sastry, V.V., Ramanujam, C.G.K., Kapoor, H.M., Rao, B.R.J., Satsangi, P.P., and Mathur, U.B. (Eds.), Symposium on three Decades of Development in Palaeontology and Stratigraphy in India - Precambrian to Mesozoic. Geological Society of India, Special Publication, v. 1(11), pp. 523-528.

Yuan, Z.-Y, Zhang, B.-L., Raxworthy, C.J., Weisrock, D.W., Mime, P.M., Jin, J.-Q., Lemmon, E.M., Lemmon, A.R., Holland, S.D., Kortyna, M.L., Zhou, W.-W., Peng, M.-S., Che, J, and Prendini, E., 2018,. Natatanuran frogs used the Indian plate to step-stone disperse and radiate across the Indian Ocean. National Science Review, v. 6(1), pp. 10-14.doi.org/10.1093/nsr/nwy092

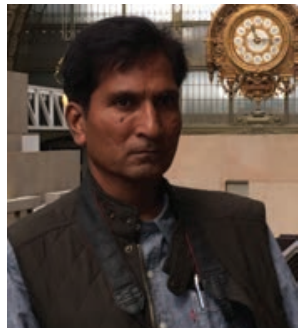

G.V.R. Prasad is currently a Professor at the Department of Geology, University of Delhi (India). He completed his Ph.D. degree in Vertebrate Palaeontology from Panjab University, Chandigarh (India) in 1986. His research covered a wide range of topics in Mesozoic Vertebrate Palaeontology of India, from the evolution and functional morphology of Mesozoic mammals to biodiversity dynamics and faunal changes during the Deccan volcanic activity, and from the evolution of Jurassic marine reptiles of pericratonic regions to taphonomy and palaeoecology of dinosaur nesting sites in Central India. In recent years, he has been focusing on the origin of life forms and patterns of their evolution and dispersals duringthe drifting phase of India.

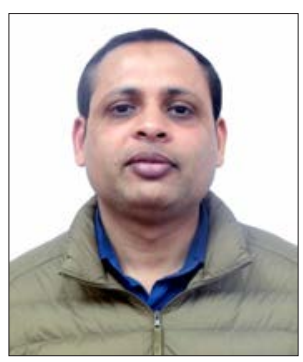

Dr. Varun Parmar is an Associate Professor in Department of Geology at University of Jammu, India. His research interests pertain to the study of Phanerozoic life of India with emphasis on Mesozoic and Cenozoic vertebrates of India in context of their diversity, evolution, biochronological, palaecological, and biogeographic implications. 